\title{
PANCASILA DASAR NEGARA INDONESIA
}

\author{
Astim Riyanto ${ }^{1}$
}

\section{Abstrak}

Pancasila is a name of basic norm (Grundnorm) of a state that is called Republic of Indonesia that standing on 17 August 1945. Pancasila was formularized by the founding fathers of Indonesia and established by Committee Preparation Freedom of Indonesia on 18 August 1945 to become fundamental state of Indonesia. The Pancasila had enclosed in the Preamble of The Constitution of The Republic of Indonesia of 1945. And then, Pancasila as national ideology, national basic unity, and guiding national behavior or way of life of people or nation of Indonesia. Thus, Pancasila is innerself of nation of Indonesia. The Pancasila had integrated a nation of Indonesia that plural. Without the Basic Norm of Pancasila will not to be Indonesia like that there is now and to future. Therefore, existence of Pancasila is the real need for insurance integration of nation and state of Indonesia.

Kata kunci: Pancasila, norma dasar, dasar negara, dasar pemersatu, pedoman perilaku bangsa Indonesia

\section{Pendahuluan}

Keputusan Panitia Persiapan Kemerdekaan Indonesia (PPKI) yang dibentuk oleh pimpinan Panglima Kesatuan Ke-16 Pemerintah Militer Jepang di Jakarta 7 Agustus 1945 dalam sidang 18 Agustus 1945 adalah pengesahaan/penetapan "Pembukaan Undang-Undang Dasar Negara Republik Indonesia Tahun 1945". Keputusan PPKI (Dokuritsu Zyunbi Iinkai) yang lainnya pada sidang hari itu adalah pengesahan/penetapan "UndangUndang Dasar Negara Republik Indonesia Tahun 1945" — bukan "UndangUndang Dasar 1945" - beserta Aturan Peralihan dan Aturan Tambahan, pemilihan dan pengangkatan Presiden dan Wakil Presiden pertama, serta

' Penulis adalah Magister dan Doktor Hukum Tata Negara spesialisasi Hukum Konstitusi dari Universitas Padjadjaran (UNPAD) Bandung, Dosen Teori dan Hukum Konstitusi di Universitas Pendidikan Indonesia (UPI) di Bandung. Buku-buku yang telah diterbitkan antara lain berjudul Teori Konstitusi (1993, 2000, 2006), Filsafat Hukum (2000, 2007), Teori Negara Kesatuan (2006), serta Negara Kesatuan Konsep, Asas, dan Aktualisasinya (2006). 
pembentukan Panitia Kecil Perancang Departemen. Bukan "Undang-Undang Dasar 1945", karena memang ketika Undang-Undang Dasar ini disahkan/ditetapkan berjudul atau bernama Undang-Undang Dasar Negara Republik Indonesia, dan sehubungan dengan dibuat tahun 1945 maka bentuknya menjadi seperti dalam Keputusan Presiden RI Nomor 150 Tahun 1959 tanggal 5 Juli 1959 mengenai Dekrit Presiden Republik Indonesia/Panglima Tertinggi Angkatan Perang Tentang Kembali Kepada Undang-Undang Dasar 1945 (Lembaran Negara 1959 Nomor 75), yang berjudul atau bernama "Undang-Undang Dasar Negara Republik Indonesia Tahun 1945".

Hal itu berarti nama resmi Undang-Undang Dasar atau Konstitusi negara Republik Indonesia adalah "Undang-Undang Dasar Negara Republik Indonesia Tahun 1945". Perubahan Undang-Undang Dasar Pertama (1999), Kedua (2000), Ketiga (2001), dan Keempat (2002) Undang-Undang Dasar Negara Republik Indonesia Tahun 1945 pun menggunakan nama ini. Memang nama "Undang-Undang Dasar Negara Republik Indonesia Tahun 1945" inilah yang benar menurut hukum (hukum positif), bukan nama "Undang-Undang Dasar 1945" yang dimuat pada Berita Republik Indonesia Tahun II Nomor 7 tanggal 15 Februari 1946 yang selama masa Orde Baru (11 Maret 1966 - 21 Mei 1998) digunakan. Namun, untuk teknis penulisan dapat disingkat UUD 1945 dalam konteks hukum nasional dan UUD RI 1945 dalam konteks hukum internasional.

Di samping itu, dengan judul atau nama "Undang-Undang Dasar 1945", maka Pembukaan Undang-Undang Dasar Negara Republik Indonesia Tahun 1945 menjadi terjangkau atau terkena oleh ketentuan Pasal 37 Undang-Undang Dasar ini yang berarti Pembukaan dapat diubah. Padahal pada saat disahkan/ditetapkan oleh PPKI, Pembukaan itu disahkan/ditetapkan lebih dulu, berada terpisah, di luar, bersifat tetap, di atas, dan tidak merupakan bagian dari Batang Tubuh Undang-Undang Dasar. Hal itu ditempatkan kembali pada posisinya dalam Keputusan Presiden RI Nomor 150 Tahun 1959. Dengan posisi ini, maka Pembukaan secara hukum tidak dapat diubah. Pembukaan yang semula berasal dari Rancangan Pembukaan Hukum Dasar Negara Indonesia yang dapat dipandang sebagai konsensus bangsa, sesudah di bahas dan dikaji secara mendalam, komprehensif, integral, dan demokratis - dalam konteks berbangsa dan bernegara Indonesia merdeka dengan wilayah kepulauan yang luas dan posisi silang strategis dari Sabang di bagian Barat hingga Merauke di bagian Timur serta dari Manado di bagian Utara hingga Cilacap di bagian Selatan yang selama sekitar 350 tahun diduduki kolonialis Belanda serta penduduk yang besar dan pluralis - pada sidang PPKI, setelah mengalami perubahan lalu 
disahkan/ditetapkan oleh badan tersebut pada 18 Agustus 1945 menjadi Pembukaan Undang-Undang Dasar Negara Republik Indonesia Tahun 1945.

Ditilik dari segi isinya, maka Pembukaan UUD 1945 tadi merupakan acuan pokok dan rumusan pokok berdirinya negara Indonesia merdeka, yang mana dalam Pembukaan UUD 1945 itu telah dicantumkan syarat-syarat primer berdirinya Negara Republik Indonesia. Syarat-syarat primer berdirinya Negara Republik Indonesia merdeka yang tertuang dalam Pembukaan UUD 1945 tadi, yaitu "rakyat Indonesia" (pada alinea kedua dan alinea keempat) atau "bangsa Indonesia" (pada alinea keempat), "Pemerintah Negara Indonesia" (pada alinea keempat) sebagai salah satu bentuk political organization (organisasi politik), dan "tumpah darah Indonesia" (pada alinea keempat). Jaminan Indonesia sebagai negara hukum dapat ditemukan dalam Pembukaan UUD 1945 yang menyatakan "... disusunlah Kemerdekaan Kebangsaaan Indonesia itu dalam suatu Undang-Undang Dasar Negara Indonesia yang terbentuk dalam suatu susunan Negara Republik Indonesia, ...". Negara hukum yang dianut UUD 1945 adalah negara hukum kesejahteraan yang mengacu kepada teori atau ajaran Rechtsstaat dari sistem hukum Eropa Kontinental dengan civil law system-nya dan teori atau ajaran Rule of Law dari sistem hukum Anglo-Sakson/Anglo-Saksis dengan commom law system-nya. Dengan adanya keharusan Negara Republik Indonesia memiliki Undang-Undang Dasar atau Konstitusi sebagai hukum tertinggi di suatu negara hukum yang menganutnya dapat memfasilitasi, mendorong, dan membangun Negara Konstitusional Republik Indonesia. Menurut Gianfranco Poggi (1978), Negara Konstitusional ini merupakan puncak perkembangan kehidupan kenegaraan dan kemasyarakatan yang secara sadar dan sistematis didasarkan pada hukum.

Syarat-syarat berdirinya Negara Republik Indonesia yang tercantum dalam Pembukaan UUD 1945 itu sejalan dengan syarat-syarat primer dari teori berdirinya suatu negara dari Wallace S. Sayre (1966) yang mengatakan

"The elements necessary to the state are usually concidered to be: (1) people, (2) territory, (3) unitary, (4) political organization, (5) sovereignty, and (6) permanence". PPKI pada saat Indonesia merdeka tanggal 17 Agustus 1945 dapat dimasukkan ke dalam kategori political organization (organisasi politik) sedangkan sebagai government (pemerintah) Indonesia baru ada pada saat PPKI memilih dan mengesahkan Presiden dan Wakil Presiden tanggal 18 Agustus 1945. Pemilihan Presiden dan Wakil Presiden pertama itu didasarkan pada klausul Pasal III Aturan Peralihan Undang-Undang Dasar Negara Republik Indonesia Tahun 1945 yang berbunyi: "Untuk pertama kali Presiden dan Wakil Presiden dipilih oleh Panitia Persiapan Kemerdekaan Indonesia". 
Di samping Pembukaan secara hukum tidak dapat diubah karena tidak terjangkau atau terkena oleh ketentuan Pasal 37 Undang-Undang Dasar, juga sejalan dengan asas hukum yang menyatakan suatu bentuk atau produk hukum hanya dapat diubah oleh suatu bentuk atau produk hukum yang sama atau lebih tinggi dari lembaga yang sama atau bentuk atau produk hukum dari lembaga yang berkedudukan lebih tinggi atau di atasnya. Dalam pada itu, lembaga atau badan yang berwenang mengesahkan/menetapkan Pembukaan dan juga Undang-Undang Dasar Negara Republik Indonesia Tahun 1945 itu adalah PPKI sebagai satu-satunya badan nasional ketika itu dan telah berfungsi serta bertindak sebagai Majelis Pembentuk UndangUndang Dasar atau Badan Konstituante. Berdasarkan Undang-Undang Dasar Negara Republik Indonesia Tahun 1945 yang disahkan/ditetapkan oleh PPKI tersebut, kewenangan seperti itu sekarang ada pada Majelis Permusyawaratan Rakyat (MPR) sebagai lembaga negara. Namun, MPR ini pun secara hukum tidak dapat mengubah Pembukaan Undang-Undang Dasar Negara Republik Indonesia Tahun 1945 itu, karena MPR hanya berwenang mengubah pasalpasal Undang-Undang Dasar.

Dalam sidang 19 Agustus 1945, PPKI menetapkan pembentukan Panitia Kecil Perancang Pengisian Program dan Susunan Daerah. Pada sidang hari itu, PPKI menerima laporan Panitia Kecil Perancang Departemen yang dibentuk oleh PPKI dalam sidangnya tanggal 18 Agustus 1945, yang membagi Kabinet menjadi atau ke dalam 12 Departemen/Kementerian dan satu Menteri Negara, yaitu Dalam Negeri; Luar Negeri; Kehakiman; Keuangan; Kemakmuran; Kesehatan; Pengajaran, Pendidikan dan Kebudayaan; Sosial; Pertahanan; Penerangan; Perhubungan; Pekerjaan Umum; dan Menteri Negara. Dalam laporannya pada hari itu, Panitia Kecil Perancang Pengisian Program dan Susunan Daerah yang dibentuk oleh PPKI pada awal rapat PPKI hari itu, merekomendasikan hal-hal yang harus mendapat perhatian lebih dulu, yaitu: (1) berkenaan dengan urusan rakyat, (2) berhubungan dengan pemerintahan daerah, (3) pimpinan kepolisian, dan (4) berhubungan dengan tentara kebangsaan. Dalam sidang bagian akhir hari itu juga, PPKI menerima hasil rumusan Panitia Kecil Perancang Pengisian Program dan Susunan Daerah, yang membagi wilayah Indonesia bekas wilayah Hindia Belanda (Nederlands Indie) menjadi atau ke dalam delapan provinsi. Kedelapan provinsi itu adalah Jawa Barat, Jawa Tengah, Jawa Timur, Sumatera, Borneo, Sulawesi, Maluku, dan Sunda Kecil.

Pertimbangan pengadministrasian wilayah Indonesia ke dalam delapan provinsi itu bersifat sementara, disesuaikan dengan sumber daya terutama sumber daya manusia terdidik yang tersedia pada saat itu. Dalam sidang 20 Agustus 1945, PPKI menetapkan Badan Penolong Keluarga Korban Perang. Dalam sidang terakhirnya tanggal 22 Agustus 1945, PPKI menetapkan 
Komite Nasional (Pusat dan Daerah) serta Partai Nasional Indonesia. Sementara itu, pada 29 Agustus 1945, karena telah selesai melaksanakan tugasnya, sebelum pelantikan 150 anggota Komite Nasional Indonesia Pusat (KNIP), Presiden membubarkan PPKI. Adapun KNIP dibentuk atas ketentuan Aturan Peralihan Undang-Undang Dasar Negara Republik Indonesia Tahun 1945 Pasal IV yang berbunyi: "Sebelum Majelis Permusyawaratan Rakyat, Dewan Perwakilan Rakyat, dan Dewan Pertimbangan Agung dibentuk menurut Undang-Undang Dasar ini, segala kekuasaannya dijalankan oleh Presiden dengan bantuan Komite Nasional".

\section{Rumusan Pancasila Dasar Negara Indonesia}

Dari uraian di atas menunjukkan dalam sidang-sidang tanggal 18, 19 , 20, dan 22 Agustus 1945 - setelah Indonesia merdeka 17 Agustus 1945 -, PPKI telah membuat sejumlah keputusan. Keputusan pertama dan terpenting adalah pengesahan Pembukaan Undang-Undang Dasar Negara Republik Indonesia Tahun 1945, yang di dalamnya terdapat rumusan dasar negara Pancasila. Menurut perjalanan sejarah naskah Pembukaan Undang-Undang Dasar ini berasal dari Rancangan Pembukaan Hukum Dasar Negara Indonesia hasil rapat Panitia Kecil Penyelidik Usul-usul/Perumus Dasar Negara yang beranggotakan sembilan orang, karena itu sering disebut Panitia Kecil Sembilan. Panitia Kecil Sembilan ini dibentuk dalam rapat anggota Badan Penyelidik Usaha-usaha Persiapan Kemerdekaan Indonesia (BPUPKI) yang dihadiri 38 anggota BPUPKI (Dokuritsu Zyunbi Tyoosakai) yang ada di Jakarta tanggal 22 Juni 1945 yang mulai bersidang pukul 20.00. Rancangan Pembukaan Hukum Dasar Indonesia hasil rapat Panitia Kecil Sembilan ini diterima oleh rapat yang dihadiri 38 anggota BPUPKI tangal 22 Juni 1945 itu juga. Ketiga puluh delapan anggota BPUPKI yang dibentuk oleh Pemerintah Militer Jepang di Jawa dan Madura 29 April 1945 itu hadir ke dalam xapa: tersebut karena diundang oleh Panitia Kecil Penampung/Pemeriksa Usi \$. usul BPUPKI yang berjumlah delapan orang, karena itu sering puià d $\mathrm{e}^{1}$ Panitia Kecil Delapan.

Panitia Kecil Delapan dibentuk pada akhir masa sidang I BPUPKI tanggal 1 Juni 1945. Panitia Kecil Delapan ini dibentuk karena \$PUPKI pada masa sidang I yang berlangsung dari tanggal 29 Mei 1945 sampai dengan 1 Juni 1945 belum mencapai kata sepakat tentang rumusan Dasar Negara Indonesia yang akan merdeka. Panitia Kecil Delapan inilah yang bertugas atau ditugasi untuk menampung, memeriksa, dan mengumpulkan pendapatpendapat dan asal-usul tertulis atau lisan yang masuk dari para anggota BPUPKI pada masa sidang I untuk dilaporkan pada masa sidang II BPUPKI 
yang ketika itu akan berlangsung tanggal 10 Juli 1945 sampai dengan $17 \mathrm{Juli}$ 1945 serta masukan usul-usul secara tertulis dari para anggota BPUPKI yang masih akan memasukkan usul-usulnya secara tertulis dari sejak penutupan sidang masa sidang I tanggal 1 Juni 1945 sampai dengan selambat-lambatnya tanggal 20 Juni 1945. Itulah sebabnya rapat Panitia Kecil Delapan bersama 30 orang anggota BPUPKI yang lain itu baru diadakan tanggal 22 Juni 1945. Dalam rangka melaksanakan tugas itulah, Panitia Kecil Delapan berinisiatif mengundang dan mengadakan rapat pada 22 Juni 1945 yang mulai bersidang pukul 10.00 dengan para anggota BPUPKI lainnya yang ada di Jakarta pada masa reses BPUPKI. Masa reses BPUPKI berlangsung sesaat setelah masa sidang I ditutup tanggal 1 Juni 1945 sampai dengan sesaat menjelang rapat paripurna atau sidang pleno yang ketika itu digunakan istilah "rapat besar" hari pertama pada masa sidang II dibuka tanggal 10 Juli 1945. Salah satu putusan yang dicapai dalam rapat itu membentuk satu Panitia Kecil Penyelidik Usul-usul/Permumus Dasar Negara (Panitia Kecil Sembilan) yang bertugas merumuskan dasar negara yang dituangkan dalam bentuk Rancangan Pembukaan atau Mukadimah Hukum Dasar. Kenyataannya. Panitia Kecil Sembilan ini dapat menyelesaikan tugasnya dengan berhasil menyusun "Rancangan Pembukaan Hukum Dasar Negara Indonesia", yang kemudian diterima dalam rapat 38 anggota BPUPKI pada 22 Juni 1945 tersebut.

Pada rapat besar hari pertama masa sidang II BPUPKI tanggal $10 \mathrm{Juli}$ 1945, Ketua Panitia Kecil Delapan (yang juga Ketua Panitia Kecil Sembilan) antara lain melaporkan proses pembentukan Panitia Kecil Sembilan pada 22 Juni 1945 dan hasil Panitia Kecil Sembilan berupa Rancangan Pembukaan Hukum Dasar Negara Indonesia yang disusun dalam rapat Panitia Kecil Sembilan pada hari itu juga, dengan harapan dapat dibahas pada rapat besar BPUPKI tanggal 10 Juli 1945 itu atau rapat-rapat besar pada masa sidang II BPUPKI atau rapat-rapat besar BPUPKI hari-hari berikutnya. Namun, harapan atau usulan sejumlah anggota BPUPKI agar "Rancangan Pembukaan Hukum Dasar Negara Indonesia" hasil rumusan Panitia Kecil Sembilan tersebut dibahas dalam rapat besar BPUPKI hari pertama masa sidang II BPUPKI tanggal 10 Juli 1945 atau pada hari itu tidak disetujui oleh Ketua BPUPKI, dengan alasan belum waktunya untuk membicarakan hal itu. Bahkan karena padatnya agenda kegiatan dan hal-hal yang harus diputuskan oleh rapat-rapat besar BPUPKI, Rancangan Hukum Dasar Negara Indonesia itu tidak sempat secara khusus dibahas pada rapat-rapat besar BPUPKI sampai habis masa sidang II BPUPKI tanggal 17 Juli 1945.

Akan tetapi, kemudian Ketua Panitia Perancang Undang-Undang Dasar (yang juga Ketua Panitia Kecil Delapan dan Ketua Panitia Kecil Sembilan) pada rapat besar BPUPKI tanggal 14 Juli 1945 melaporkan 
rancangan "Pernyataan Indonesia Merdeka" yang juga sebagai rancangan "Teks Proklamasi" yang cukup panjang, yang kalau dilihat dari segi isi naskahnya merupakan perluasan yang bersifat historis perjuangan pergerakan bangsa Indonesia dari alinea kesatu, kedua, dan ketiga Rancangan Pembukaan Hukum Dasar Negara Indonesia dan Rancangan "Pembukaan Undang-Undang Dasar" yang lebih singkat dari naskah rencana "Pernyataan Indonesia Merdeka", yang kalau dilihat dari segi isi naskahnya telah sedikit mendapat tambahan dari alinea keempat Rancangan Pembukaan Hukum Dasar Negara Indonesia. Kedua naskah rancangan ini merupakan hasil rumusan Panitia Kecil Perancang Declaration of Rights yang dibentuk pada rapat Panitia Perancang Undang-Undang Dasar tanggal 11 Juli 1945. Panitia Perancang Undang-Undang Dasar, - serta Panitia Pembelaan Tanah Air dan Panitia Keuangan dan Perekonomian - dibentuk pada rapat besar BPUPKI tanggal 10 Juli 1945. Pada rapat besar BPUPKI tanggal 14 Juli 1945 itu juga kedua rancangan tersebut setelah mengalami pembahasan intensif diterima bulat oleh para anggota BPUPKI. Namun, karena perubahan dan perkembangan cepat setelah Jepang mengumumkan menyerah tanpa syarat kepada Sekutu tanggal 14 Agustus 1945 (de facto) dan penandatangan dokumen Jepang menyerah tanpa syarat kepada Sekutu antara Pemerintah Jepang dan Sekutu di Tokyo tanggal 15 Agustus 1945 (de jure), kedua naskah rancangan atau teks itu tidak sempat dibahas lagi dan bahkan kemudian tidak tergunakan. Para pendiri negara Indonesia menggunakan Pembukaan dari Rancangan Pembukaan Hukum Dasar Negara Indonesia hasil rumusan Panitia Kecil Sembilan tanggal 22 Juni 1945 yang diterima dalam rapat 38 anggota BPUPKI pada tanggal atau hari itu juga dan menggunakan Teks Proklamasi dari rencana Teks Proklamasi hasil rumusan Panitia Kecil Penyusunan Teks Proklamasi Kemerdekaan Indonesia beranggotakan lima orang yang dibentuk dan bekerja tanggal 17 Agustus 1945 dini hari (antara pukul 24.00 - 03.00 waktu Jawa zaman pendudukan Jepang menjelang Proklamasi Kemerdekaan Indonesia tanggal 17 Agustus 1945 pukul 10.00 waktu Jawa zaman Pendudukan Jepang di halaman depan Jalan Pegangsaan Timur 56 Jakarta.

Prof.Mr.H.Muhammad Yamin dalam kapasitas sebagai anggota BPUPKI yang juga kemudian selaku guru besar bidang hukum dan pakar Hukum Konstitusi (The Law of The Constitution) ketika itu menyebut "Rancangan Pembukaan Hukum Dasar Negara Indonesia" dengan "Piagam Jakarta" (Jakarta Charter) dan dr. Soekiman Wirjosandjojo dalam kapasitas sebagai anggota BPUPKI menyebutnya dengan "Gentlemen Agreement". Rancangan Pembukaan Hukum Dasar Negara Indonesia tersebut terwujud pada saat mengkristalnya desakan, tuntutan, keinginan, dan kemauan bangsa Indonesia merdeka selekas-lekasnya. Selanjutnya, istilah "Piagam Jakarta" 
itu memperoleh pengakuan yuridis melalui konsiderans kelima atau terakhir Keputusan Presiden RI Nomor 150 Tahun 1959, yang menyatakan : "Bahwa kami berkeyakinan bahwa Piagam Jakarta tertanggal 22 Juni 1945 menjiwai Undang-Undang Dasar 1945 dan adalah merupakan suatu rangkaian kesatuan dengan konstitusi tersebut".

Dalam Pembukaan Undang-Undang Dasar Negara Republik Indonesia Tahun 1945 alinea keempat atau terakhir bagian akhir terdapat rumusan yang menyatakan: Ketuhanan Yang Maha Esa, Kemanusiaan yang adil dan beradab, Persatuan Indonesia, dan Kerakyatan yang dipimpin oleh hikmat kebijaksanaan dalam permusyawaratan/perwakilan, serta dengan mewujudkan suatu Keadilan sosial bagi seluruh rakyat Indonesia. Rumusan itu terjalin secara harmonis, hirarkis, piramidal, terpadu, padat, utuh, bulat, dan menyeluruh, di mana sila pertama "Ketuhanan Yang Maha Esa" yang menyinari dan mendasari keempat sila yang lain dari rumusan itu. Prof. Dr. Drs. Notonagoro, S.H. mengatakan, "Ke-Tuhanan Yang Maha Esa adalah meliputi dan menjiwai sila-sila kemanusiaan yang adil dan beradab, persatuan Indonesia, kerakyatan yang dipimpin oleh hikmat kebijaksanaan dalam permusyawaratan/perwakilan, keadilan sosial bagi seluruh rakyat Indonesia".

Menurut tinjauan atau penafsiran historis, rumusan dalam alinea keempat bagian akhir Pembukaan Undang-Undang Dasar Negara Republik Indonesia Tahun 1945 yang disahkan/ditetapkan oleh PPKI tanggal 18 Agustus 1945 yang berupa sila-sila dan terdiri atas lima sila itu dinamakan Pancasila. Perumusan definitifnya merupakan hasil perumusan ulang dan pemantapan perumusan secara sistematis, hirarkis, dan sinergis oleh the founding fathers (para pendiri negara) Indonesia yang disesuaikan dengan kedudukan Pancasila sebagai filsafat negara dan dasar negara Indonesia merdeka yang menganut kedaulatan rakyat (popular sovereignty) dan kerakyatan (democracy) sebagai konsekuensi keberadaan bangsa Indonesia sebagai isi negara Republik Indonesia yang serba pluralistik (bhinneka). Bahan mentah dari rumusan Pancasila yang terdapat dalam Pembukaan Undang-Undang Dasar Negara Republik Indonesia Tahun 1945 itu antara lain berasal dari masukan rumusan-rumusan Pancasila, yaitu dari rumusan asas dasar negara Indonesia merdeka dalam pidato dan konsep tertulis diserahkan sesaat setelah pidato yang rumusannya terdapat perbedaan urutan dan redaksional dengan rumusan dalam pidato Prof.Mr. H.Muhammad Yamin dalam rapat besar BPUPKI tanggal 29 Mei 1945, dari masukan rumusan asas dasar negara Indonesia merdeka dalam pidato Prof. Mr. Dr. R. Soepomo dalam rapat besar BPUPKI tanggal 31 Mei 1945, serta dari rumusan asas dasar negara Indonesia merdeka dalam pidato Ir.Soekarno dalam rapat besar BPUPKI tanggal 1 Juni 1945, dan dari masukan rumusan 
Pancasila dalam Rancangan Pembukaan Hukum Dasar Negara Indonesia dalam rapat Panitia Kecil Sembilan yang kemudian diterima oleh rapat 38 anggota BPUPKI - yang diselenggarakan pada masa reses BPUPKI tanggal 22 Juni 1945.

Adapun penggunaan istilah Pancasila itu sendiri berasal dari atau mengacu kepada materi rapat besar BPUPKI tanggal 1 Juni 1945 yang ketika itu dalam sidang resmi BPUPKI tersebut diintroduksi suatu istilah bahasa Indonesia yang semula berasal dari bahasa Sansekerta, yaitu Pancasila. Nama ini terlontar dan mencuat ke permukaan dalam konteks sebuah nama untuk nama dasar negara Indonesia merdeka di wilayah nusantara yang saat itu sedang dicari dan digali dari budaya (kultur) yang bhinneka bangsa Indonesia sendiri oleh para pendiri negara Indonesia, yang rumusannya secara yuridiskonstitusional dimaksudkan seperti yang tercantum dalam Pembukaan Undang-Undang Dasar Negara Republik Indonesia Tahun 1945 tadi. Oleh karena rumusan Pancasila terdapat dalam Pembukaan Undang-Undang Dasar Negara Republik Indonesia Tahun 1945 di mana Undang-Undang Dasar tersebut sebagai hukum tertinggi yang tidak dapat diubah secara hukum (hukum positif), maka Pancasila dasar negara Indonesia ber-sifat final dan mengikat bagi seluruh lembaga negara beserta lembaga subdivisinya, organisasi kemasyarakatan, kelompok, dan perseorangan warga negara Indonesia.

Prof. Dr. Drs. Notonagoro, S.H. (1967) mengatakan, lima unsur yang tercantum di dalam Pancasila bukanlah hal-hal yang timbul baru pada pembentukan negara Indonesia, tetapi sebelumnya dan selama-lamanya telah dimiliki oleh rakyat, bangsa Indonesia, yang nyata ada dan hidup dalam jiwa masyarakat, rakyat dan bangsa Indonesia. Hal itu dipertegas dengan Instruksi Presiden RI Nomor 12 Tahun 1968 tanggal 13 April 1968 tentang Tata Urutan dan Rumusan Dalam Penulisan/ Pembacaan/Pengucapan Sila-sila Pancasila, sebagaimana tercantum dalam Pembukaan Undang-Undang Dasar Negara Republik Indonesia Tahun 1945, yang antara lain menyatakan "... supaya sila-sila dalam Pancasila dibaca/diucapkan dengan tata urutan dan rumusan ...". Rumusan Pancasila yang terdapat dalam Rancangan Pembukaan Hukum Negara Indonesia tersebut disusun oleh Panitia Kecil Penyelidik Usul-usul/Perumus Dasar Negara BPUPKI berdasarkan masukan dari segenap anggota BPUPKI yang hendak menjawab pertanyaan dan tantangan yang diajukan oleh Ketua BPUPKI dr. K.R.T. Radjiman Wedyodiningrat pada awal rapat besar pertamanya tanggal 29 Mei 1945, yaitu: "Indonesia merdeka apa dasarnya?".

Jadi, yang dicari adalah dasar negara dan yang berhasil ditemukan/dirumuskan pun dasar negara, bukan yang lain. Oleh karena itu, adalah tepat pada alinea keempat Pembukaan Undang-Undang Dasar Negara 
Republik Indonesia Tahun 1945 menyatakan "... suatu susunan Negara Republik Indonesia yang berkedaulatan rakyat dengan berdasar kepada Ketuhanan Yang Maha Esa, Kemanusiaan yang adil dan beradab, Persatuan Indonesia, dan Kerakyatan yang dipimpin oleh hikmat kebijaksanaan dalam permusyawaratan/perwakilan, serta dengan mewujudkan suatu Keadilan sosial bagi seluruh rakyat Indonesia". Naskah Pembukaan Undang-Undang Dasar Negara Republik Indonesia Tahun 1945 yang berasal dari Rancangan Pembukaan Hukum Dasar Negara Indonesia setelah dilakukan penyesuaian tersebut disahkan/ditetapkan oleh PPKI dalam sidangnya tanggal 18 Agustus 1945. Dalam pada itu, naskah Undang-Undang Dasar Negara Republik Indonesia Tahun 1945 yang tanpa atau belum dengan Penjelasannya pada mulanya berasal dari naskah Rancangan Undang-Undang Dasar rumusan Panitia Kecil Perancang Undang-Undang Dasar dalam rapatnya tanggal 12 Juli 1945 yang kemudian dibahas dalam rapat Panitia Perancang UndangUndang Dasar tanggal 13 Juli 1945 serta rapat besar BPUPKI tanggal 15 dan 16 Juli 1945 yang diterima dalam rapat besar BPUPKI tanggal 16 Juli 1945 itu juga. Naskah Penjelasan Undang-Undang Dasar baru muncul dengan dimuat dalam Berita Republik Indonesia Tahun II Nomor 7 tanggal 15 Februari 1946. Dalam kehidupan kenegaraan/ketatanegaraan Republik Indonesia, sejak Pembukaan dan Undang-Undang Dasar itu disahkan/ditetapkan oleh PPKI dan berlaku di seluruh Indonesia dari tanggal 18 Agustus 1945 sampai dengan tanggal 27 Desember 1949 dan sejak Pembukaan dan Batang Tubuh Undang-Undang Dasar Negara Republik Indonesia Tahun 1945 yang secara resmi telah disertai dengan Penjelasannya diberlakukan kembali melalui Keputusan Presiden RI Nomor 150 Tahun 1959 tanggal 5 Juli 1959 sampai dengan sekarang.

Pada masa Republik Indonesia Serikat/Konstitusi Negara Republik Indonesia Serikat 1949 yang berlaku dari tanggal 27 Desember 1949 sampai dengan tanggal 17 Agustus 1950 dan masa Negara Kesatuan Republik Indonesia/Undang-Undang Dasar Sementara Republik Indonesia 1950 yang berlaku dari tanggal 17 Agustus 1950 sampai dengan tanggal 5 Juli 1959, maka Undang-Undang Dasar Negara Republik Indonesia Tahun 1945 tidak berlaku kecuali di Negara Bagian RI Yogyakarta masih tetap berlaku pada masa Republik Indonesia Serikat/Konstitusi Negara Republik Indonesia Serikat 1949. Sejak 5 Juli 1959 itulah Pembukaan dan Undang-Undang Dasar beserta Penjelasannya tersebut sebagai hukum positif di seluruh Indonesia yang memiliki kekuatan berlaku dan kekuatan mengikat yuridiskonstitusional. Adapun Penjelasan UUD 1945 sejak Perubahan Keempat UUD 1945 tanggal 10 Agustus 2002, berdasarkan Pasal II Aturan Tambahan tidak berlaku lagi. Pasal II Aturan Peralihan tersebut berbunyi : "Dengan ditetapkannya perubahan Undang-Undang Dasar ini, Undang-Undang Dasar 
Negara Republik Indonesia Tahun 1945 terdiri atas Pembukaan dan pasalpasal".

Dengan demikian, jelas kedudukan pertama dan utama Pancasila itu adalah sebagai dasar negara, bukan sebagai yang lain, di mana Pancasila sebagai dasar negara dibentuk setelah menampung dan menyerap berbagai pandangan yang berkembang secara demokratis dari para anggota BPUPKI dan PPKI sebagai representasi bangsa Indonesia ketika itu. Apabila dasar negara Pancasila dihubungkan dengan cita-cita dan tujuan negara/nasional, maka jadilah ideologi negara/nasional Pancasila. Cita-cita dan tujuan nasional itu pun telah termaktub dalam Pembukaan Undang-Undang Dasar Negara Republik Indonesia Tahun 1945. Cita-cita nasional Indonesia dimaksud termaktub pada alinea kedua bagian akhir yang menyatakan "Negara Indonesia yang merdeka, bersatu, berdaulat, adil dan makmur". Oleh karena cita-cita merdeka, bersatu, dan berdaulat telah tercapai, maka lazim disebutkan cita-cita negara RI adalah "adil dan makmur" atau "masyarakat adil dan makmur", lengkapnya "masyarakat adil dan makmur, baik material maupun spiritual". Sementara itu, tujuan nasional Indonesia dimaksud termaktub pada alinea keempat bagian awal yang menyatakan "melindungi segenap bangsa Indonesia dan seluruh tumpah darah Indonesia dan untuk memajukan kesejahteraan umum, mencerdaskan kehidupan bangsa, dan ikut melaksanakan ketertiban dunia yang berdasarkan kemerdekaan, perdamaian abadi dan keadilan sosial". Oleh karena itu, dalam konteks ini, ideologi nasional dapat dimaknai sebagai sistem kehidupan nasional yang meliputi aspek politik, ekonomi, sosial budaya, dan pertahanan keamanan dalam rangka pencapaian cita-cita dan tujuan bangsa yang telah menegara berlandaskan dasar negaranya, yang untuk Indonesia adalah Pancasila. Ideologi nasional ini, secara sosiologis juga merupakan ideologi masyarakat, di mana menurut Soerjono Soekanto, S.H., M.A. (1975), "ideologi masyarakat yang merupakan dasar integrasi masyarakat tersebut".

\section{Pancasila Sebagai Dasar Pemersatu Bangsa Indonesia}

Suatu bangsa dalam suatu komunitas solidaritas - tidak terkecuali bangsa Indonesia - yang terobsesi hendak membangun menjadi bangsa yang besar (antara lain menetap di suatu wilayah yang luas sebagai salah satu syarat suatu bangsa atau negara akan menjadi besar), kuat (antara lain dengan dukungan sumber daya alam yang secara akumulatif menjadi banyak dan memadai serta saling melengkapi/ mendukung antardaerah), maju (antara lain dengan dukungan ilmu pengetahuan, teknologi dan seni (ipteks) serta iman dan taqwa (imtaq) untuk mencapai kesejahteraan umum/bersama), dan 
bermartabat (antara lain dengan dijunjung tinggi human dignity dan human rights) dengan topangan persatuan dan kesatuan yang kokoh dapat memilih dan menentukan dasar negara yang sesuai dengan kondisi pluralitas rakyat, bentuk dan luas wilayah, corak pemerintahan berkaitan dengan budaya masyarakatnya, dan hubungannya dengan negara lain terutama negara-negara yang terletak di sekitarnya. Bangsa Indonesia melalui para pendiri negara pada menjelang dan awal berdiri negaranya telah berhasil secara bebas dan penuh tanggung jawab demi persatuan dan kesatuan, keutuhan, serta kejayaan bangsanya di masa jauh ke depan, tanpa tekanan atau paksaan dari pihak mana pun menentukan Pancasila sebagai dasar negara.

Ditinjau dari stufenbau des rechts theorie (teori pertingkatan hukum) menurut Prof. Hans Kelsen, maka Pancasila itu berkedudukan sebagai Grundnorm (Norma Dasar/Kaidah Dasar). Grundnorm merupakan kaidah tertinggi, fundamental, dan menjadi inti (kern) dari setiap tatanan kaidah hukum dalam masyarakat yang teratur, termasuk di dalamnya negara, pada dasarnya tidak berubah-ubah melainkan relatif "abadi". Grundnorm atau dapat juga disebut Staatsgrundnorm ini berada di atas Undang-Undang Dasar atau Konstitusi. Sementara itu, Undang-Undang Dasar atau Konstitusi itu merupakan hukum tertinggi di dalam tatanan hukum nasional suatu negara. Oleh karena itu, Grundnorm itu bersifat metayuridis.

Dihubungkan dengan ajaran dari mazhab sejarah hukum yang dipelopori oleh Prof. Friedrich Carl von Savigny, yang pandangannya bertitik tolak di dunia ini terdapat banyak bangsa dan tiap-tiap bangsa tadi memiliki suatu volksgeist (jiwa rakyat, jiwa bangsa), maka Pancasila dapat digolongkan sebagai volksgeist bangsa Indonesia. Menurut Prof.Dr.Hans Nawiasky, dalam suatu negara yang merupakan kesatuan tatanan hukum terdapat suatu kaidah tertinggi, yang kedudukannya lebih tinggi dari UndangUndang Dasar atau Konstitusi. Berdasarkan kaidah yang tertinggi inilah Undang-Undang Dasar atau Konstitusi suatu negara dibentuk. Prof.Dr.Hans Nawiasky memberi nama kepada kaidah tertinggi dalam kesatuan tatanan hukum dalam negara itu dengan Staatsfundamentalnorm (Kaidah Fundamental Negara), yang untuk bangsa Indonesia berupa Pancasila. Hakikat hukum suatu Staatsfundamentalnorm ialah syarat bagi berlakunya suatu Undang- Undang Dasar atau Konstitusi. Ia ada terlebih dulu sebelum adanya Undang-Undang Dasar atau Konstitusi. Staatsfundamentalnorm mempunyai akar langsung pada kehendak sejarah suatu bangsa, dasar yang membentuk negara tersebut, yang menurut Prof. Dr. Carl Schmitt merupakan keputusan bersama atau konsensus sifat dan bentuk suatu kesatuan politik yang diambil bangsa tersebut.

Dalam pada itu, para ahli Etnologi seperti seorang Amerika Serikat Frans Boas melalui sebuah karangan tentang Suku Bangsa Eskimo Tengah 
(1888), A.R. Radcliffe-Brown melalui bukunya The Andaman Islanders (1922) dan Bronislaw Malinowski melalui bukunya The Argonauts of the Western Pacific melukiskan masyarakat dan kebudayaan sebagai satu kesatuan (totalitas) yang menimbulkan konsep kebudayaan sebagai "the total way of life of a people", yang kemudian menimbulkan pula konsepsi "social structure". Dari sudut pandang ini, Pancasila sebagai pedoman perilaku atau cara hidup (way of life) rakyat atau bangsa Indonesia, yang kemudian melahirkan social structure negara Indonesia.

Berkenaan dengan persoalan dasar negara Indonesia merdeka, antara lain tiga orang dari 63 orang yang tergabung dalam BPUPKI mengajukan pemikirannya, yaitu Prof.Mr.H.Muhammad Yamin, Prof. Mr. Dr. R. Soepomo, dan Ir. Soekarno. Dalam rapat besar BPUPKI tanggal $29 \mathrm{Mei}$ 1945, Prof. Mr. H. Muhammad Yamin selaku anggota badan tersebut mengajukan konsep lima asas dasar negara Indonesia merdeka melalui pidato dan menyampaikan konsep lima asas dasar negara Indonesia merdeka tertulis yang diserahkan sesaat setelah pidato, di mana antara kedua konsep atau rumusan tersebut pada asasnya sama tetapi terdapat perbedaan urutan dan redaksional. Dalam rapat besar BPUPKI tanggal 31 Mei 1945, Prof. Mr. Dr. R. Soepomo selaku anggota badan tersebut yang sebagai guru besar bidang hukum serta bapak dan pakar Hukum Adat berkebangsaan Indonesia mengajukan pemikiran Dasar Negara Integralistik atau Kekeluargaan yang lazim atau lebih dikenal dengan Asas Integralistik - dari Negara Kebangsaan Indonesia merdeka yang berdasar atas semangat kebudayaan Indonesia yang asli. Dimaksud dengan Negara Integralistik atau Kekeluargaan, yaitu negara yang teratur dan bersatu dengan seluruh rakyatnya, yang mengatasi seluruh golongan-golongannya dalam lapangan apa pun. Negara yang mengakui dan menghormati adanya golongangolongan dalam masyarakat yang nyata sebagai bagian organik dari negara seluruhnya.

Dalam rapat besar BPUPKI tanggal 1 Juni 1945, Ir.Soekarno selaku anggota badan tersebut mengajukan asas dasar negara Indonesia merdeka yang beliau beri nama Pancasila. Prof. Dr. Drs. Notonagoro, S.H. (1967) dalam suatu orasi ilmiah mengintroduksikan nama Pokok Kaidah Fundamental Negara/Pokok Kaidah Fundamental dari Negara/Pokok Kaidah Negara yang Fundamental dan asas kerohaniaan negara. Prof. Dr. Drs. Notonagoro, S.H. (1967) dalam suatu orasi ilmiah mengintroduksikan nama Pokok Kaidah Fundamantel Negara/Pokok Kaidah Fundamental dari Negara/Pokok Kaidah Negara yang Fundamental dan asas kerohaniaan negara. Menurut Prof. Dr. Drs. Notonagoro, SH., Pancasila mempunyai kedudukan sebagai asas kerohaniaan negara yang berada dalam Pembukaan 
Undang-Undang Dasar Negara Republik Indonesia Tahun 1945 yang berkedudukan sebagai Pokok Kaidah Fundamental Negara.

Penjelasan Undang-Undang Dasar Negara Republik Indonesia Tahun 1945, pada bagian Umum, Angka II dan Angka III, menyatakan UndangUndang Dasar menciptakan pokok-pokok pikiran yang terkandung dalam Pembukaan dalam pasal-pasalnya. Pokok-pokok pikiran yang terkandung dalam Pembukaan Undang-Undang Dasar meliputi: (1) negara persatuan yang melindungi dan meliputi segenap bangsa Indonesia seluruhnya di mana negara mengatasi segala paham golongan dan paham perseorangan, (2) negara hendak mewujudkan keadilan sosial bagi seluruh rakyat, (3) negara yang berkedaulatan rakyat berdasarkan atas kerakyatan dan permusyawaratan/perwakilan, serta (4) negara berdasar atas Ketuhanan Yang Maha Esa menurut dasar kemanusiaan yang adil dan beradab. Keempat pokok pikiran yang terkandung dalam Pembukaan Undang-Undang Dasar itu tidak lain adalah penjabaran cita-cita Pancasila yang sesuai dengan sifa masyarakat Indonesia. Pokok-pokok pikiran ini mewujudkan cita-cita hukum (rechtsidee) yang menguasai hukum dasar negara, baik hukum yang tertulis maupun hukum yang tidak tertulis.

Menurut Prof. Dr. Drs. Notonagoro, S.H. peraturan-peraturan hukum bersama merupakan suatu tertib hukum apabila memenuhi empat syarat, yaitu: (1) ada kesatuan subjek (penguasa) yang mengadakan peraturanperaturan hukum, (2) ada kesatuan asas kerohaniaan yang meliputi (menjadi dasar dari) keseluruhan peraturan-peraturan hukum itu, (3) ada kesatuan daerah di mana keseluruhan peraturan-peraturan hukum itu berlaku, dan (4) ada kesatuan waktu dalam mana keseluruhan peraturan-peratuan hukum itu berlaku. Dalam kalimat (alinea) keempat dari Pembukaan Undang-Undang Dasar Negara Republik Indonesia Tahun 1945 terdapat empat hal yang menjadi syarat bagi adanya suatu tertib hukum itu. Dengan adanya suatu Pemerintah Republik Indonesia maka ada kesatuan subjek (penguasa), adanya Pancasila maka ada asas kesatuan kerohaniaan, disebutkannya seluruh tumpah darah Indonesia maka ada kesatuan daerah, dan disebutkannya disusunlah kemerdekaan bangsa Indonesia dalam bentuk negara maka timbullah suatu masa baru yang terpisah dari waktu yang lampau. Dengan demikian, peraturan-peraturan hukum yang ada dalam negara Republik Indonesia mulai saat berdirinya negara Republik Indonesia itu merupakan suatu tertib hukum, yaitu tertib hukum Indonesia.

Selanjutnya, Prof.Dr.Drs.Notonagoro,SH. menyatakan di dalam tertib hukum dapat diadakan pembagian susunan yang hirarkis. Undang-Undang Dasar tidak merupakan peraturan (baca: dasar) yang tertinggi. Di atasnya masih ada dasar pokok bagi Undang-Undang Dasar atau hukum dasar yang tidak tertulis yang dalam hakikatnya terpisah dari Undang-Undang Dasar 
atau convention, yang dinamakan Pokok Kaidah Negara yang Fundamental (Staatsfundamentalnorm). Pokok Kaidah Negara yang Fundamental itu menurut pengertian ilmiah mengandung dua unsur mutlak. Pertama, dalam hal terjadinya, ditentukan oleh pembentuk negara dan terjelma dalam suatu bentuk penyataan lahir (ijabkabul) sebagai penjelmaan kehendak pembentuk negara untuk menjadikan hal-hal tertentu sebagai dasar-dasar negara yang dibentuk. Kedua, dalam hal isinya, memuat dasar-dasar negara yang dibentuk, atas dasar cita-cita kerohaniaan (asas kerohaniaan negara), atas dasar cita-cita negara (asas politik negara), dan untuk cita-cita negara (tujuan negara) negaranya dibentuk dan diselenggarakan serta memuat ketentuan diadakannya Undang-Undang Dasar negara, jadi merupakan sebab berada, sumber hukum dari Undang-Undang Dasar negara. Norma hukum yang pokok yang disebut Pokok Kaidah Fundamental dari Negara itu, dalam hukum mempunyai hakikat dan kedudukan yang tetap, kuat, dan tidak berubah bagi negara yang dibentuk, dengan lain perkataan dengan jalan hukum tidak lagi dapat dirubah. Pembukaan tidak dapat ditiadakan/dirubah dengan jalan hukum oleh penguasa/alat-alat perlengkapan negara yang mana pun juga. Mengingat setelah negara Republik Indonesia berdiri, semua penguasa negara yang ada atas ketentuan Undang-Undang Dasar adalah alatalat perlengkapan negara yang kedudukannya di bawah pembentuk negara pada waktu negara dibentuk, maka atas prinsip suatu peratuan hukum hanya dapat ditadakan/dirubah oleh penguasa yang sama atau lebih tinggi kedudukannya.

Ditegaskan oleh Prof. Dr. Drs. Notonagoro, SH., Pembukaan UndangUndang Dasar Negara Republik Indonesia Tahun 1945 itu menurut sejarah terjadinya, ditentukan oleh Pembentuk Negara sebagai penjelmaan kehendaknya yang dalam hakikatnya dipisahkan dari Undang-Undang Dasar, dan menurut isinya memuat asas kerohaniaan negara (Pancasila), asas politik negara (republik yang berkedaulatan rakyat), tujuan negara (melindungi segenap bangsa Indonesia dan seluruh tumpah darah Indonesia dan untuk memajukan kesejahteraan umum, mencerdaskan kehidupan bangsa, dan ikut melaksanakan ketertiban dunia yang berdasarkan kemerdekaan, perdamaian abadi dan keadilan sosial), lagi pula menetapkan adanya suatu UndangUndang Dasar Indonesia. Jadi, Pembukaan dalam segala sesuatunya memenuhi syarat-syarat mutlak bagi suatu Pokok Kaidah Negara yang Fundamental menurut pengertian ilmiah.

Bagi Negara Republik Indonesia dengan penduduknya kini sekitar 220 juta jiwa - merupakan jumlah terbesar keempat di dunia setelah Republik Rakyat Cina, Republik India, dan Republik Amerika Serikat - dengan wilayah kepulauan yang luas dan posisi silang strategis serta penduduk yang besar dan pluralitas tinggi, jika masih berkehendak atau berkeinginan 
membentuk dan membangun suatu negara (persatuan dan kesatuan) yang kuat, besar, maju, bermartabat, dan disegani negara lain jelas membutuhkan dasar negara yang berfungsi sebagai daya ikat, pengikat atau perekat kohesif, serta dasar pemersatu bangsa dan negara. Dasar negara Indonesia dimaksud dalam Pancasila. Meskipun demikian, Pancasila tetap sebagai ideologi terbuka, terutama pada tataran nilai praksis dan dimungkinkan penyesuaian terutama kinerja pada tataran nilai instrumental, tetapi tidak pada tataran nilai fundamental berupa rumusan Pancasila.

\section{Langkah-langkah Dalam Mendudukkan Pancasila Dasar Negara Indonesia}

Dalam Penjelasan Undang-Undang Dasar Negara Republik Indonesia Tahun 1945, pada Sistem Pemerintahan Negara, Angka I secara eksplisit menyatakan "Indonesia ialah negara yang berdasarkan atas hukum (Recthsstaat)". Pada Angka 1-nya menegaskan "Negara Indonesia berdasar atas hukum (Recthsstaat), tidak berdasarkan atas kekuasaan belaka (Machtsstaat)". Pada Angka II menyatakan "Sistem Konstitusional", yang kemudian pada Angka 2-nya menandaskan "Pemerintahan berdasarkan atas sistem konstitusi (hukum dasar), tidak bersifat absolutisme (kekuasaan yang tidak terbatas)". Penjelasan tersebut, selanjutnya dipertegas dengan Pasal 1 ayat (3) Perubahan Ketiga Undang-Undang Dasar Negara Republik Indonesia Tahun 1945 yang berbunyi "Negara Indonesia adalah negara hukum".

Dengan mengacu kepada Indonesia sebagai negara hukum, baik dalam pengertian Rechtsstaat (istilah berasal dari tradisi hukum Eropa Konstinental yang bersumber pada civil law system) maupun pengertian Rule of Law (istilah yang berasal dari tradisi hukum Anglo Saxon yang bersumber pada common law system), maka langkah-langkah yang diperlukan dalam mendudukkan Pancasila dasar negara Indonesia adalah melakukan langkahlangkah sesuai dengan esensi dari unsur-unsur negara hukum itu sendiri. Langkah-langkah yang diperlukan dalam mendudukkan Pancasila dasar negara Indonesia tadi meliputi mengakui dan melaksanakan jaminan hak asasi manusia dan warga negara, menerima dan menerapkan pembagian dan pembatasan kekuasaan, menghormati dan menegakkan hukum yang berlaku, serta menghargai dan mentaati putusan kekuasaan kehakiman yang merdeka.

Pertama, mengakui dan melaksanakan jaminan hak asasi manusia dan warga negara. Mengenai pengakuan dan pelaksanaan hak asasi/dasar manusia dan warga negara telah mendapat jaminan dari hukum internasional melalui Deklarasi Universitas tentang Hak-hak Manusia (Universal 
Declaration of Human Rights) yang disahkan Majelis Umum (MU) Perserikatan Bangsa-Bangsa (PBB) tanggal 10 Desember 1948 di mana menegaskan asas-asas umum hak-hak berikut perangkat-nya yaitu kebebasan dan persamaan. Untuk menguatkan Deklarasi dan sejalan dengan sistem demokrasi kemanusiaan, maka PBB mengeluarkan perjanjian-perjanjian internasional terinci. Yang penting dua Perjanjian Internasional yang diratifikasi MU PBB tanggal 16 Desember 1966, yaitu Perjanjian Internasional Khusus tentang Hak-hak Sipil dan Politik (International Covenant on Civil and Political Rights) dan Perjanjian Internasional Khusus tentang Ekonomi, Sosial, dan Kebudayaan (International Covenant on Economic, Social and Cultural Rights). Beberapa persetujuan (konvensi) yang relevan dengan prinsip umum persamaan, yaitu Persetujuan Melawan Diskriminasi dalam Pendidikan (Convention Against Discrimination in Education) dikeluarkan oleh United Nations Educational, Scientific and Cultural Organization (UNESCO) tahun 1960 dan Persetujuan Internasional untuk Menghilangkan Bentuk-bentuk Diskriminasi Rasial (Internasional Convention on the Elimination of all forms Racial Discrimination) dibentuk PBB tahun 1965.

PBB tidak merasa cukup hanya dengan deklarasi-deklarasi yang bersifat umum, maka mengeluarkan deklarasi-deklarasi khusus dan rinci mengenai hak-hak wanita. Yang terpenting adalah Persetujuan tentang Hakhak Politik Wanita dan Deklarasi Menghilangkan Diskriminasi terhadap Wanita. Deklarasi tentang Hak-hak Anak telah diterbitkan oleh MU PBB tahun 1959. Deklarasi Vienna dan Program Aksi (The Vienna Declaration and Programme of Action) telah disusun dan diputuskan oleh Konferensi Dunia Hak Asasi Manusia bulan Juni 1993. Guna mendukung pengakuan dan pelaksanaan hak asasi manusia di tingkat internasional telah dibentuk oleh PBB sebuah organisasi bernama Komisi Ahli Hukum Internasional (Internasional Commission of Jurists) yang sejak tahun 1955 telah melakukan berbagai konferensi, deklarasi, dan kuliah umum. Di samping itu, telah dibentuk lembaga Amnesti Internasional, yaitu organisasi khusus yang didirikan seorang pengacara Inggris Peter Benenson tahun 1962 di London.

Dalam hukum nasional Indonesia, jaminan hak asasi/dasar manusia telah diatur dalam Pasal-pasal 27, 28, 28A-28J, 29, 30, 31, 32, 33, dan 34 Undang-Undang Dasar Negara Republik Indonesia Tahun 1945 sebelum dan sesudah Perubahan Kedua tanggal 18 Agustus 2000. Selanjutnya, selain dalam Undang-Undang Dasar jaminan hak asasi manusia di Indonesia diatur pula dalam Ketetapan Majelis Permusyawaratan Rakyat (MPR) RI Nomor XVII/MPR/1998 tanggal 13 November 1998 tentang Hak Asasi Manusia dan Undang-Undang RI Nomor 39 Tahun 1999 tanggal 23 September 1999 tentang Hak Asasi Manusia. Khusus mengenai pengadilannya diatur dalam 
Undang-Undang RI Nomor 26 Tahun 2000 tanggal 23 November 2000 tentang Pengadilan Hak Asasi Manusia. Di samping itu, Undang-Undang RI Nomor 5 Tahun 1998 tanggal 28 September 1998 tentang Pengesahan Convention Against Torture and Other Cruel, Ihuman or Degrading Treatment of Punishment (Konvensi Menentang Penyiksaan dan Perlakuan atau Penghukuman Lain yang Kejam, Tidak Manusiawi, atau Merendakan Martabat Manusia; Keputusan Presiden RI Nomor 181 Tahun 1998 tanggal 9 Oktober 1998 tentang Komisi Nasional Anti Kekerasan Terhadap Perempuan; Keputusan Presiden RI Nomor 129 Tahun 1998 tanggal 15 Agustus 1998 tentang Rencana Aksi Nasional Hak-hak Asasi Manusia Indonesia; Instruksi Presiden RI Nomor 26 Tahun 1998 tanggal 16 September 1998 tentang Menghentikan Penggunaan Istilah Pribumi dan Nonpribumi dalam Semua Perumusan dan Penyelenggaraan Kebijakan Perencanaan Program, ataupun Pelaksanaan Kegiatan Penyelenggaraan Pemerintahan. Untuk keperluan penegakan hak asasi/dasar manusia dan warga negara di Indonesia telah dibentuk Komisis Nasional Hak Asasi Manusia melalui Keputusan Presiden RI Nomor 50 Tahun 1993 tanggal 7 Juni 1993.

Kedua, menerima dan menerapkan pembagian dan pembatasan kekuasaan. Pada prinsipnya seluruh negara di dunia menganut dan menggunakan ajaran pemisahan kekuasaan (separation of powers) dari Charles de Secondat Baron de Labriede et de Montesquieu, di mana menurut beliau kekuasaan dalam suatu negara itu dipisahkan menjadi atau ke dalam tiga kekuasaan (trias politica) yang satu sama lain terpisah, yaitu legislatif, eksekutif, dan yudikatif. Sementara itu, the founding fathers negara Indonesia tidak menentukan pemisahan kekuasaan, melainkan pembagian kekuasaan (division of powers). Pembagian kekuasaan ini dilakukan secara vertikal dan horizontal antara suprastruktur politik beserta perangkatnya, yang kemudian diikuti dengan pemencaran kekuasaan (distribution of powers) yang dilakukan secara vertikal melalui implementasi asas-asas penyelenggaraan pemerintahan di daerah (asas desentralisasi, asas dekonsentrasi, dan asas tugas pembantuan) dari atas dalam hal ini Pemerintah Pusat ke bawah dalam hal ini Pemerintahan Daerah. Begitu pula suprastruktur politik di negara Indonesia berdasarkan Undang-Undang Dasar Negara Republik Indonesia Tahun 1945 dan perubahannya tidak tiga lembaga negara (legislatif, eksekutif, dan yudikatif), melainkan delapan lembaga negara yaitu Majelis Permusyawaratan Rakyat, Dewan Perwakilan Rakyat, Dewan Perwakilan Daerah, Presiden, Badan Pemeriksa Keuangan, Mahkamah Agung, Komisi Yudisial, dan Mahkamah Konstitusi. Adapun kinerja dan prestasi kerja dari lembaga-lembaga negara ini tergantung kepada "semangat, semangat para penyelenggara Negara, semangat para pemimpin 
pemerintahan" (Penjelasan Undang-Undang Dasar Negara Republik Indonesia Tahun 1945, bagian Umum, Angka IV. Undang-Undang Dasar Bersifat Singkat dan Supel).

Ketiga, menghormati dan menegakkan hukum yang berlaku. Hukum yang berlaku di sini dapat berupa hukum tertulis (yang terdiri atas peraturan perundang-undangan, baik dikodifikasi maupun tidak dikodifikasi; yurisprudensi; dan perjanjian-perjanjian internasional) dan hukum tidak tertulis (yang berupa hukum kebiasaan dan hukum adat). Agar hukum itu berdaya guna dan berhasil guna, maka hukum harus dijadikan sebagai dasar, rangka, strategi, sarana, alur, dan arah pembaharuan dan pembangunan, baik pembangunan fisik (material) maupun pembangunan non-fisik (spiritual).

Keempat, menghargai dan mentaati putusan kekuasaan kehakiman yang merdeka. Berdasarkan Pasal 10 ayat (3) Undang-Undang RI Nomor 32 Tahun 2004 tanggal 15 Oktober 2004 tentang Pemerintahan Daerah, kewenangan peradilan tidak termasuk yang diserahkan kepada Daerah Otonom melainkan berada pada Pemerintah Pusat. Menurut Pasal 24 ayat (1) Undang-Undang Dasar Negara Republik Indonesia Tahun 1945 menyatakan : "Kekuasaan Kehakiman dilakukan oleh sebuah Mahkamah Agung dan lainlain badan kehakiman menurut undang-undang". Menurut penjelasan Pasal 24 dan 25 Undang-Undang Dasar Negara Republik Indonesia Tahun 1945 menerangkan: "Kekuasaan kehakiman ialah kekuasaan yang merdeka artinya terlepas dari pengaruh kekuasaan Pemerintah. Berhubungan dengan hal itu harus diadakan jaminan dalam Undang-Undang tentang kedudukannya para hakim". Menurut Pasal 10 Undang-Undang RI Nomor 14 Tahun 1970 tentang Ketentuan-ketentuan Pokok Kekuasaan Kehakiman, dalam kekuasaan kehakiman di Indonesia terdapat empat lingkungan peradilan, yaitu peradilan umum, peradilan agama, peradilan militer, dan peradilan tata usaha negara. Keempat lingkungan peradilan tersebut pada dasarnya berada di setiap Daerah Kabupaten/Kota dan Daerah Provinsi, kemudian berpuncak pada Mahkamah Agung yang berkedudukan di ibukota negara, dalam hal ini di Jakarta.

Dengan menempuh langkah-langlah tadi sekaligus dapat memantapkan pelaksanaan Otonomi Daerah yang pada gilirannya memperkokoh semangat persatuan dan kesatuan bangsa dan Negara Kesatuan Republik Indonesia yang berbentuk kepulauan yang luas dan posisi silang strategis dengan penduduk yang besar dan pluralis. Sebaliknya, apabila penegakan negara yang berdasarkan hukum dan sistem konstitusional kurang diperhatikan atau diabaikan, maka kepastian hukum tidak berjalan, kemakmuran masyarakat atau rakyat terabaikan, rasa keadilan di masyarakat dapat terkesampingkan, dan hak asasi manusia - yang menurut bapak hak asasi manusia John Locke meliputi hak hidup, hak bebas, dan hak milik - dapat terlecehkan. Dalam 
suasana seperti ini, hukum akan lebih diimplementasi-kan sebagai alat penertiban semata untuk merepresif pihak-pihak di bawah pengaruh seseorang, sekelompok atau segolongan orang penguasa yang secara subjektif dipandang atau diduga akan menghalangi atau menghambat penetrasi dan akselerasi kelangsungan atau kelanjutan kekuasaan, kepentingan, atau kepemimpinannya yang lebih bersifat pribadi atau kelompok atau lebih luas mungkin golongan tadi daripada untuk kepentingan umum, bangsa, dan negara. Kalau sudah demikian halnya, maka dapatlah sinyalemen yang berupa peringatan bijak seorang ilmuwan kerajaan Inggris bernama John Emerick Edwerd Dalberg Acton yang akrab dipanggil Lord Acton yang menyatakan "Power tends to corrupt, but absolute power corrupts absolutely" (Manusia yang mempunyai kekuasaan cenderung untuk menyalahgunakannya, tetapi manusia yang mempunyai kekuasaan absolut sudah pasti akan menyalahgunakannya) menjadi benar adanya.

Dalam situasi demikian, jika penegakan hukum dalam mencapai citacita dan tujuan nasional atau suatu lembaga lemah atau melemah, memungkinkan munculnya fenomena sentralisme, uniformisme, otoritarianisme, absolutisme, diktatorisme, despotisme. Selanjutnya, memungkinkan pula timbulnya gejala praktik-praktik nepotisme, primordialisme, monopoli, monopsoni, oligopoli, oligopsoni, kolusi, korupsi. Pemerintah (government) atau pimpinan elite suatu lembaga secara perlahan dapat berubah dan mengental menjadi seperti sebuah negara dalam negara. Terjadilah ekslusivisme. Kultus individu mungkin sukar dihindari. Partisipasi warga negara, anggota lembaga atau warga masyarakat yang merupakan salah satu syarat penting untuk mencapai keberhasilan pembangunan dan pengembangan lembaga ke masa jauh ke depan menjadi sesuatu yang langka, bahkan asing atau dengan sengaja diasingkan.

Oleh karena menurut pandangan rezim (suatu varian/variant sistem pemerintahan tertentu dan para pemimpin pendukungnya) seperti ini partisipasi lebih banyak mengganggu daripada membantu. Tentu saja pandangan seperti ini akan terkesan benar adanya apabila dilihat dari kepentingan sempit dan serba jangka sesaat bukan untuk jangka pendek, jangka menengah, dan jangka panjang. Dalam keadaan seperti itu jauhlah terwujudnya tata penyelenggaraan pemerintahan yang baik (good governance) yaitu suatu tata penyelenggaraan pemerintahan negara yang berjalan secara efektif dan efisien dengan menjaga kesinergian interaksi yang konstruktif antara negara, swasta, dan masyarakat yang bercirikan bersih, ber-wibawa, transparansi, persamaan, partisipasi, profesional, pengambilan keputusan bottom up, menghormati hak asasi manusia, menjunjung supremasi hukum, dan akuntabilitas publik. Jauhlah pula terwujudnya masyarakat madani atau masyarakat sipil (civil society) yang bercirikan 
menjunjung tinggi democracy, rule of law, egalitarian, human dignity, plurality, modern, social solidarity, equilibrium, dan religiousity menjadi trend masyarakat dunia, dengan era globalisasinya. Lebih jauh lagi terwujudnya negara konstitusional atau negara kesejahteraan yang demokratis (negara hukum material). Dalam masyarakat yang menolak trend ini, seolah sejarah berjalan mundur. Konsekuensinya harga sosial yang harus dibayar terlalu mahal : kehidupan statis. Oleh karena itu, dalam menghadapi perubahan dan pembaharuan kehidupan umat manusia di bola bumi yang akibat pengaruh sains dan teknologi terasa seperti semakin mengecil ini sangat tepat Pancasila diposisikan sebagai ideologi terbuka.

\section{Kendala Yang Mungkin Timbul Dalam Mendudukkan Pancasila Dasar Negara Indonesia}

Ditinjau dari segi efektivitas hukum dalam tatanan negara hukum Indonesia, kendala yang mungkin timbul dalam upaya mendudukkan Pancasila dasar negara Indonesia dapat dilihat dari aspek-aspek peraturannya, kelembagaannya, penegaknya, fasilitasnya, dan masyarakatnya.

Pertama, dari aspek peraturannya. Peraturan atau peraturan perundangundangan yang baik akan dibuat secara umum berdasarkan pertimbangan filosofis, yuridis, dan sosiologis. Dengan memperhatikan persyaratan tersebut, maka peraturan bernilai keadilan (filosofis), sah karena dibuat oleh yang berwenang (yuridis), dan dapat diterima karena sesuai dengan kebutuhan masyarakat (sosiologis). Untuk suatu peraturan dapat menjadi hukum positif (hukum yang berlaku pada suatu tempat, waktu, dan masyarakat tertentu), maka peraturan harus memiliki kekuatan peraturan (disahkan oleh yang berwenang), kekuatan berlaku peraturan (hasil pekerjaan pembuat peraturan), dan kekuatan mengikat peraturan (telah diumumkan/ diundangkan menurut ketentuan yang berlaku). Apabila suatu peraturan yang dibuat tidak berdasarkan prosedur dan bermateri muatan seperti itu, maka jelas pelaksanaan peraturan itu akan menghadapi kendala. Tidak tertutup kemungkinan suatu peraturan sejak disahkan dan diberlakukan banyak menghadapi tentangan (resistance) dari pihak yang terkena peraturan itu atau bahkan tidak dapat dilaksanakan sama sekali.

Kedua, dari aspek kelembagaannya. Suatu peraturan dapat diterapkan di tengah-tengah kehidupan masyarakat apabila ada lembaga (institution) penyeleng-garanya. Oleh karena itu, agar suatu peraturan dapat dilaksanakan harus tersedia, disediakan atau kalau belum ada dibentuk terlebih dulu lembaga-lembaga yang akan melaksanakan peraturan itu. Apabila suatu peraturan yang dibuat lembaga penyelenggaraannya tidak mampu 
melaksanakan, maka jelas pelaksanaan peraturan itu akan menghadapi kendala. Bahkan kalau tidak ada lembaga penyelenggaranya, maka praktis peraturan itu tidak dapat dilaksanakan.

Ketiga, dari aspek penegaknya. Visi dan misinya, semangatnya, profesionalismenya, dan unsur lainnya yang berkaitan erat dengan pelaksanaan tugas, kewajiban, dan wewenang dari penegak hukum bukan saja akan mewarnai penegakan hukum (law enforcement), tetapi bahkan sebagai instansi terakhir di lapangan akan menentukan keberhasilan di semua strata penegakan hukum dengan segala variasi dan dimensinya. Oleh karena itu, yang harus menjadi catatan penting adalah dalam rekruitmen para hakim agar dalam seleksinya dan pengangkatan para pejabat di lingkungan peradilan dan lembaga-lembaga penegak hukum lainnya melalui uji kelayakan dan kepatutan (fit and proper test) termasuk dan diberi tekanan pada aspek-aspek loyalitas, komitmen, dedikasi, keahlian, kesejawatan, kemampuan, kepemimpinan, dan kecerdasan mendapat perhatian yang seksama dan khusus. Sebenarnya proses rekruitmen serta uji kemampuan dan kelayakan seperti itu seyogianya diberlakukan juga bagi seluruh pegawai negeri sipil dan militer. Apabila suatu peraturan yang dibuat tidak didukung oleh penegak yang profesional, maka pelaksanaan peraturan itu akan menghadapi kendala. Tidak tertutup kemungkinan suatu peraturan berjalan tersendat-sendat, mengambung, atau mandeg.

Keempat, dari aspek fasilitasnya. Aspek ini secara keseluruhan mungkin bukan merupakan yang terpenting dalam pelaksanaan peraturan. Namun, tanpa ada gedung, peralatan, kendaraan, dan lainnya termasuk pendanaan, dapat saja terjadi suatu kegiatan peradilan atau kegiatan penegakan hukum lainnya menjadi terganggu, terhambat, atau tidak jalan sama sekali. Oleh karena itu, aspek fasilitas termasuk pendanaan ini penting juga dalam kerangka melaksanakan suatu peraturan.

Kelima, dari aspek masyarakatnya. Dari suatu masyarakat ke suatu masyarakat yang lain memang bervariasi cara (usages), tradisi (traditions), adat istiadat (customs), kebiasaan (folkways), tata kelakuan (mores), pengertian/kesepahaman/kesepakatan (understandings), konvensi (conventions), bahasa, budaya, kaidah (norm), keyakinan dan agama, juga bervariasi tingkat pendidikan, ekonomi, dinamika, kesadaran hukum, rasa keadilan dan ekspektasi kehidupannya. Oleh karena itu, pelaksanaan peraturan di lapangan harus memperhatikan variabel-variabel tersebut di atas. Hal itu sesuai dengan definisi masyarakat dari seorang antropolog Ralph Linton dalam bukunya The Study of Man (1936) yang mengemukakan masyarakat ialah setiap kelompok manusia yang telah cukup lama hidup dan bekerja sama sehingga mereka itu dapat mengorganisasikan dirinya dan berpikir tentang dirinya sebagai satu kesatuan sosial dengan batas-batas 
tertentu. John Lewis Gillin dan John Philip Gillin dalam buku mereka Culture Sociology (1948) yang mengatakan masyarakat ialah kelompok manusia yang terbesar yang mempunyai kebiasaan, tradisi, sikap, dan perasaan persatuan yang sama. Masyarakat itu meliputi pengelompokanpengelompokan lebih kecil. Seorang sosiolog Belanda S.R. Steinmetz dalam bukunya Inleiding tot de Sociologie (1952) mengutarakan masyarakat sebagai kelompok manusia yang terbesar yang meliputi pengelompokanpengelompokan manusia yang lebih kecil yang mempunyai perhubungan erat dan teratur. Prof. Robert M. MacIver dalam bukunya Society, An Introductory Analysis (1955) memaparkan masyarakat ialah satu sistem dari cara kerja dan prosedur, dari otoritas dan saling bantu-membantu yang meliputi kelompok-kelompok dan pembagian-pembagian sosial lain, sistem dari pengawasan tingkah laku manusia dan kebebasan. Sistem yang kompleks yang selalu berubah, atau jaringan-jaringan dari relasi sosial itulah yang dinamai masyarakat. Masyarakat tadi mempunyai kebudayaan. Seorang antropolog Edward Burnett Tylor dalam bukunya Primitive Culture (1871) mengemukakan kebudayaan ialah satu keseluruhan yang kompleks, yang di dalamnya terkandung pengetahuan, kepercayaan, kesenian, moral, hukum, adat istiadat, dan kemampuan-kemampuan yang lain serta kebiasaankebiasaan yang didapat oleh manusia sebagai anggota dari suatu masyarakat.

Jika variabel-variabel dalam masyarakat itu tidak diperhatikan bukan saja tidak akan memenuhi rasa keadilan masyarakat, melainkan dapat melukai citra dan hati nurani masyarakat. Kalau hal itu terjadi maka hukum akan dipandang berada di luar kehidupan suatu masyarakat, bahkan bisa jadi diposisikan berseberangan atau lebih parah diposisikan berlawanan dengan kebutuhan dan kepentingan mereka. Efeknya masyarakat akan apatis, sensitif, tidak percaya kepada hukum, dan mungkin diikuti dengan tindakan destruktif seperti perusakan, pembakaran, main hakim sendiri. Hukum yang demikian serta merta akan terkesampingkan dan masyarakat akan membuat "hukum baru" yang sesuai dengan kebutuhan dan kepentingan mereka. Hukum baru ini dikenal khasanah kehidupan kenegaraan atau ketatanegaraan misalnya hukum revolusi seperti yang terjadi di Inggris tahun 1688, di Amerika tahun 1776, di Perancis tahun 1779 - 1789, di Indonesia tahun 1945. Ini sesuai dengan doktrin dari seorang ahli tentang negara dan hukum bangsa Romawi bernama Marcus Tullius Cicero (106-43 SM) yang mengatakan "ubi societas ibi ius" (di mana ada masyarakat di situ ada hukum). Sebab bagi Marcus Tullius Cicero, hukum itu adalah satu-satunya ikatan dalam negara. Keadaan ini juga sejalan dengan ajaran tokoh mazhab sejarah hukum Prof. Friedrich Carl von Savigny yang mengatakan das Recht wird nicht gemacht, est ist und wird mit dem Volke (Hukum itu tidak dibuat. tetapi tumbuh dan berkembang bersama Masyarakat). 
Dengan mengatasi kemungkinan timbulnya kendala dalam pelaksanaan peraturan seperti terurai di atas, maka dapat memberi kontribusi yang berarti dalam mendudukkan Pancasila dasar negara Indonesia.

\section{Upaya Mengatasi Kendala Dalam Mendudukkan Pancasila Dasar Negara Indonesia}

Dari segi hukum, dalam mengupas upaya mengatasi kendala dalam mendudukkan Pancasila dasar negara Indonesia dapat menggunakan konsep pemerintahan negara yang demokratis berdasarkan hukum rumusan Internasional Commission of Jurists dalam South - East Asian and Pacific Conference of Jurists di Bangkok tahun 1965 yang bercirikan perlindungan konstitusional atas jaminan hak-hak individu, badan kehakiman yang bebas dan tidak memihak, pemilihan umum yang bebas, kebebasan untuk menyatakan pendapat, kebebasan berorganisasi dan beroposisi, serta pendidikan kewarganegaraan.

Pertama, perlindungan konstitusional atas jaminan hak-hak individu. Salah satu aspek materi muatan konstitusi menurut Prof. Dr. H.R. Sri Soemantri Martosoewignjo, S.H. adalah adanya jaminan terhadap hak-hak individu atau hak asasi/dasar manusia dan warga negara, selain materi muatan lainnya yaitu ditetapkannya susunan ketatanegaraan suatu negara yang bersifat fundamental, serta adanya pembagian dan pembatasan tugas ketatanegaraan yang bersifat fundamental. Jaminan terhadap hak-hak individu ini sesuai dengan prinsip modern constitution, normative constitution, dan living constitution, maka hak-hak tadi ditegakkan dengan sungguh-sungguh tanpa kecuali. Tegakkan senantiasa asas legalitas dan usahakan hindari asas oportunitas.

Kedua, badan kehakiman yang bebas dan tidak memihak. Terbuka kemungkinan yang luas terjadi penyimpangan dan penyalahgunaan wewenang pada penyelenggaraan negara (eksekutif). Akan tetapi, juga terdapat kemungkinan terjadi penyimpangan pada sejumlah anggota legislatif dan aparat yudikatif. Oleh karena itu, satu-satunya lembaga yang memiliki kewenangan dan kemampuan profesional mengawasi dan menindak para pelanggar hukum adalah badan kehakiman. Agar putusan badan ini mencerminkan rasa keadilan yang didambakan masyarakat, maka sangat pada tempatnya dan seharusnyalah badan kehakiman itu memiliki kebebasan dan tidak memihak dalam melaksanakan fungsi, tugas, wewenang, dan kewajibannya.

Ketiga, pemilihan umum (pemilu) yang bebas. Tidak ada satu cara pun dalam pemerintahan demokrasi perwakilan selain penyelenggaraan pemilu 
untuk mengisi lembaga-lembaga perwakilan dan juga Kepala Negara dan Kepala Pemerintahan pada negara dengan bentuk pemerintahan republik dan sistem pemerintahan presidensial atau Kepala Pemerintahan pada negara dengan bentuk pemerintahan kerajaan dan sistem pemerintahan parlementer. Distrorsi dalam penyelenggaraan pemilu seperti tidak luber (langsung, umum, bebas, dan rahasia) dan jurdil (jujur dan adil), maka terhadap hasil pemilu tadi akan menyebabkan berkurangnya legitimasi dan kredibilitas yang dipilihnya. Sekaligus pelaksanaan demokrasinya cacat, bobotnya merosot, dan mutunya rendah.

Keempat, kebebasan menyatakan pendapat. Kebebasan (di samping ketertiban, keamanan, keadilan, dan kesejahteraan) menurut Prof. Charles E. Merriam merupakan salah satu tujuan negara, baik secara internal (dalam lingkungan hukum nasional) maupun secara eksternal (dalam lingkungan hukum internasional). Kebebasan juga merupakan salah satu indikator adanya kehidupan demokrasi, di samping indikator lain yaitu persamaan, partisipasi, toleransi, transparansi, dan akuntabilitas publik. Kebebasan untuk menyatakan pendapat ini telah dijamin dalam Pasal 28 Undang-Undang Dasar Negara Republik Indonesia Tahun 1945 yang berbunyi : "Kemerdekaan berserikat dan berkumpul, mengeluarkan pikiran dengan lisan dan tulisan dan sebagianya ditetapkan dengan undang-undang". Selanjutnya, kebebasan menyatakan pendapat ini telah diatur mekanismenya dengan Undang-Undang RI Nomor 9 Tahun 1998 tentang Kemerdekaan Menyampaikan Pendapat Di Muka Umum.

Kelima, kebebasan berorganisasi dan beroposisi. Kehadiran hak-hak ber-organisasi ini sesuai dengan hasrat manusia untuk berasosasi, di mana negara sebagai wujud konkret asosiasi yang memiliki kedaulatan tertinggi di tengah-tengah organisasi lainnya di masyarakat. Dalam pada itu, kehadiran hak-hak beroposisi tidak semata-mata dalam konteks interaksi atau proses sosial terdapat persaingan dan pertentangan seperti menurut Kimball Young sebagaimana dikutip Soerjono Soekanto, S.H.,M.A. (1975), melainkan juga merupakan cetusan hasrat manusia untuk menyampaikan pesan dan memperbaiki keadaan termasuk dalam kehidupan bermasyarakat, berbangsa, dan bernegara. Oleh karena itu, mewujudkan hak-hak berorganisasi dan hakhak beroposisi sepanjang dalam koridor hukum dalam konteks negara hukum yang demokratis itu pada asasnya sangat positif, karena sesuai pula dengan naluri manusia sebagai zoon politicon. Dengan kebebasan berorganisasi, seseorang atau sekelompok orang dapat menjalin pergaulan, bekerja sama, serta mengembangkan diri dan kelompok dalam konstelasi kepentingan bangsa, negara, dan kemaslahatan umat manusia. Dengan kebebasan beroposisi dalam hal ini dapat dimaknai terdapat nuansa perbedaan pendapat secara konstruktif, suatu organisasi atau masyarakat termasuk negara dapat 
berkembang, karena bila terjadi penyimpangan akan segera mendapat koreksi. Kebebasan beroposisi di sini bisa dalam bentuk lembaga formal, tetapi bisa pula dalam bentuk fungsi. Di Indonesia selama ini lebih terjadi praktik oposisi dalam bentuk fungsi.

Keenam, pendidikan kewarganegaraan. Penduduk warga negara dan nonwarga negara Indonesia memang sangat majemuk (pluralistis). Hal itu terdapat antara lain pada aspek suku bangsa, ras, cara, tradisi, adat istiadat, kebiasaan, tata kelakuan, kesepahaman, konvensi, bahasa, budaya, kaidah, keyakinan dan agama, serta golongan. Dalam konteks ini sangat tepat semboyan "Bhinneka Tunggal Ika". Dengan beragamnya kemajemukan penduduk terutama yang warga negara Indonesia, maka terjadi perbedaan yang cukup tajam bahkan mungkin pertentangan perspesi terhadap kehidupan berbangsa dan bernegara Indonesia. Begitu pula persepsi terhadap penghayatan dan pemahaman hak dan kewajiban selaku warga negara. Sekaitan dengan hal ini, maka penting dan mendesak penyelenggaraan pendidikan kewarganegaraan (civic education) secara memadai pada pendidikan persekolahan (pendidikan dasar atau bahkan sejak pendidikan prasekolah hingga pendidikan tinggi) dan pendidikan luar sekolah (kursus, bimbingan, pelatihan, penataran, dan sejenisnya) dalam rangka pengindonesiaan (indonesianization) bangsa Indonesia serta kesadaran berbangsa dan bernegara Indonesia melalui pembentukan warga negara yang baik (good citizen).

Dalam menempuh upaya mengatasi kendala di atas harus dilakukan dalam cakupan mengatasi kemungkinan terjadi pertikaian elite politik, konflik horizontal, kemelut bangsa, dan dampak negatif globalisasi. Upaya tersebut juga harus mampu mengembangkan praktik kehidupan bermasyarakat, berbangsa, dan bernegara yang sesuai dengan nilai-nilai yang terkandung dalam Pancasila, khususnya dalam lembaga kenegaraan dan lembaga pemerintahan. Sehubungan dengan hal itu, agar Pancasila dasar negara Indonesia itu dapat berkembang sesuai dengan tuntutan perkembangan masyarakat dan tantangan zaman, maka perlu ada upaya mendorong lembaga-lembaga tertentu untuk lebih berperan aktif melakukan pengembangan Pancasila in theory dan Pancasila in action. Untuk tidak terjadi Pancasila itu seperti milik penguasa dengan serba indoktrinatif dan agitatif melalui lembaga yang khusus dibentuk untuk itu seperti Badan Pembinaan Pendidikan Pelaksanaan Pedoman Penghayatan dan Pengamalan Pancasila (BP-7), maka dalam upaya pelestarian dan pengembangan Pancasila dasar negara Indonesia, lembaga yang rentan kooptasi dari penguasa (dan terbuka kemungkinan dari pengusaha, penguasa yang pengusaha, atau pengusaha yang penguasa) seperti itu harus dihindari. 
Oleh karena itu, sebaiknya lembaga yang netral dengan berkadar objektivitas dan etika ilmiah tinggi seperti Lembaga Ilmu Pengetahuan Indonesia (LIPI), Badan Penelitian dan Pengkajian Teknologi (BPPT), dan Perguruan Tinggi (PT) dengan lembaga-lembaga yang ada di dalamnya yaitu Fakultas, Lembaga Penelitian, dan Lembaga Pengabdian Kepada Masyarakat secara terkoordinasi dapat diberi tugas untuk itu. Lembaga-lembaga yang netral dengan berkadar objektivitas dan etika ilmiah tinggi tersebut dapat memberikan persepsi dan evaluasi mendasar secara sentrifugal dan sentripetal terhadap langkah-langkah yang telah, sedang, dan akan dilaksanakan oleh pemerintah terutama sejak reformasi dicanangkan dalam upaya melestarikan dan mengembangkan nilai-nilai fundamental, instrumental, dan praksis Pancasila. Sudah tentu lembaga-lembaga netral lainnya seperti pers nasional yang antara lain mempunyai fungsi melakukan pengawasan sosial terhadap pemerintah dan masyarakat serta lembaga swadaya masyarakat dapat dilibatkan dalam upaya tadi.

Di samping itu, keteladanan penyelenggaraan negara/pemerintah (pusat dan daerah) dan para elite politik dalam menegakkan nilai-nilai Pancasila diperlukan sebagai patron perwujudan perilaku yang diikuti masyarakat dan bangsa pada lapisan yang lebih luas. Dalam kaitan dengan hal itu terutama kepada pimpinan negara dan juga para elite politik dituntut untuk berjiwa dan berpribadi negarawan dalam memegang dan mengemban amanat kepemimpinannya. Kepada mereka dituntut pula untuk dengan cermat memahami tanda-tanda zaman dan melakukan upaya pencerahan kehidupan bangsa agar dapat membawa bangsa ini melewati masa-masa sulit dan mencapai kejayaannya.

Bangsa Indonesia harus bersyukur kepada Allah SWT, Tuhan Yang Maha Esa sebagaimana telah terungkap pada awal alinea ketiga Pembukaan UUD 1945 yang menyatakan "Atas berkat rakhmat Allah yang maha kuasa ...", yang telah menganugerahi bangsa Indonesia sebuah tanah air beserta seisinya yang mempunyai kesempatan, peluang, dan ruang untuk menjadi negara besar bahkan negara adi kuasa (super power state). Hal itu dapat dilihat dari bangsa Indonesia tidak hanya telah memiliki dasar negara serta memenuhi persyaratan negara merdeka dengan mempunyai persyaratan primer atau adanya unsur-unsur primer berdirinya suatu negara yang berdiri sendiri, yaitu wilayah, penduduk, dan pemerintahan yang berdaulat atau organisasi politik yang sah dalam hal ini PPKI, melainkan telah mempunyai potensi Negara Republik Indonesia menjadi sebuah negara besar bahkan negara adi kuasa tadi.

Potensi Negara Republik Indonesia dapat menjadi sebuah negara besar bahkan negara adi kuasa karena telah memiliki kemerdekaan, kedaulatan penuh, lambang negara Garuda Pancasila, bendera nasional merah putih, lagu 
kebangsaan Indonesia Raya, bahasa Indonesia sebagai bahasa negara/kebangsaan/persatuan, solidaritas bangsa sebagai bangsa Indonesia, berkonstitusi tertulis dalam hal ini UUD 1945, kebudayaan nasional yang berasal dari kebudayaan nasional yang diperkaya oleh pluralitas kebudayaan bangsa sendiri yang berasal dari kemajemukan cara, tradisi, adat istiadat, kebiasaan, tata kelakuan, kesepahaman, konvensi, bahasa, budaya, kaidah, agama, latar belakang perjalanan sejarah daerah, dan kebudayaan dari luar bangsa Indonesia yang positif, terletak di pusat pertukaran, pergaulan, dan perabadan bangsa-bangsa di dunia, dan bentuk negara kesatuan. Di samping itu, Negara Republik Indonesia telah memiliki wilayah yang luas, letak wilayah berada di antara dua benua yakni benua Asia dan benua Australia serta dua lautan (samudra) yaitu lautan Hindia (Indonesia) dan lautan Pasifik, terletak pada posisi silang dan strategis di tengah-tengah lalu lintas transportasi perdagangan internasional, kekayaan alam (flora, fauna, dan mineral) yang berlimpah, berada di belahan bumi tropis yang subur, jumlah penduduk yang besar yang saat ini menduduki pada urutan keempat (setelah Republik Rakyat Cina, Republik India, Republik Amerika Serikat) di dunia, dan masyarakat yang religius. Dalam hal persyaratan sekunder yaitu adanya pengakuan negara lain dan kemampuan berhubungan dengan negara lain dari awal kemerdekaan Negara Republik Indonesia telah memilikinya secara memadai bahkan telah meraih prestasi dan reputasi gemilang di antaranya dalam Konfederasi Asia Afrika/Asia Africa Conference (berlangsung di Bandung tahun 1955), Perhimpunan Bangsa-Bangsa Asia Tenggara/ Association of South East Asian Nations/ASEAN (berdiri tahun 1967).

\section{Penutup}

Sebenarnya tidak sulit atau bahkan sangat mudah atau akan berjalan secara alamiah (natural) dalam mengembangkan Pancasila sebagai dasar negara dan ideologi nasional itu, karena ia digali dari dan bersumber pada kristalisasi nilai-nilai dasar yang ada di nusantara dan pada budaya (kultur) yang bhinneka bangsa Indonesia sendiri seandainya pemahaman implementasi ke arah itu cukup memadai. Dalam hubungan dengan belum cukup memadai pemahaman implementasi dari sementara kalangan masyarakat bangsa Indonesia terhadap Pancasila sebagai dasar negara dan ideologi nasional itulah upaya melestarikan Pancasila harus diletakkan. Dengan segala upaya terurai di atas pada gilirannya diharapkan perilaku kalangan masyarakat dan bangsa yang sesuai dengan nilai-nilai Pancasila dalam rentang waktu tertentu dapat diwujudkan. 
Kepada para sarjana, pakar, atau ahli ilmu politik terletak tugas yang berat untuk mendampingi filsafat (weltanschauung) Pancasila dengan teoriteori politik secara sistematis dan integral tetapi mudah dimengerti oleh seluruh lapisan rakyat (Fred Isjwara, S.H., LL.M.. 1974). Hal serupa, dari segi hukumnya dilakukan oleh para sarjana, pakar, atau ahli ilmu hukum termasuk sarjana ilmu hukum tata negara. Selanjutnya, kedua kelompok sarjana ilmu tersebut ditunjang kelompok sarjana, pakar, atau ahli ilmu lain seperti ilmu sejarah, ilmu filsafat, etika, antropologi. sosiologi, ilmu ekonomi, psikologi, pendidikan, dan lainnya secara terkoordinasi dan kontinyu bekerja sama guna menghasilkan teori-teori mutakhir untuk pemahaman dasar negara dan ideologi negara yang implementatif sejalan dengan dinamika masyarakat dan tantangan zaman. 


\section{Daftar Pustaka}

Al Rasjid, Harun. Sekitar Proklamasi, Konstitusi, dan Dekrit Presiden, Jakarta: Pelita Ilmu, 1966.

Anwar, Chaerul. Konstitusi dan Kelembagaan Negara, Jakarta: CV. Novindo Pustaka Mandiri, 1999.

Bakkry, Noor MS. Pancasila Yuridis Kenegaraan, Edisi Kedua, Yogyakarta: Liberty, 1987.

Barents, J. Ilmu Politika The Wetenschap der Politiek een Terreinverkenning), Terdjemahan L.M. Storus, Jakarta: PT. Pembangunan, 1958.

Budiardjo, Miriam. Dasar-dasar Ilmu Politik, Cetakan VI (Diterbitkan pertama kali 1972, Cetakan I 1977), Jakarta: PT. Gramedia, 1981.

Cassese, Antonio. Hak Asasi Manusia Di Dunia Yang Berubah (Human Rights in a Changing World), Penerjemah A.Rahman Zainuddin, Edisi Pertama, Jakarta: Yayasan Obor Indonesia, 1994.

Corwin, Edward S. Understanding the Constitution, New York: The Dryden Press, 1949.

Cranton, Maurice. Human Rights Today, Bombay: Manaktalas, 1962.

Darmodihardjo, Dardji. Orientasi Singkat Pancasila Dilengkapi Dengan Pedoman Penghayatan \& Pengalaman Pancasila (Ketetapan MPR No. II/MPR/1978, Malang: Lembaga Penerbitan Universitas Brawijaya, 1979.

, Santiaji Pancasila Suatu Tinjauan Filosofis, Historis dan YuridisKonstitusional, Surabaya: Usaha Nasional, 1988.

Davidson, Scott. Hak Asasi Manusia Sejarah, Teori dan Praktek Dalam Pergaulan Internasional (Human Rights. Open University Press, Buckingham, 1993), Diterjemahkan oleh A. Hadyana Pudjaatmaka, Cetakan Pertama, Jakarta: PT. Pustaka Utama Grafiti, 1994.

Dicey, Albert Venn. An Introduction to Study of the Law of the Constitution, $10^{\text {th }}$ Ed., London: English Language Book Society and Macmillan, 1952.

Djojoadisuryo, Ahmad Subardjo. Lahir Republik Indonesia (Suatu Tindjauan dan Kisah Pengalaman), Jakarta: PT. Kinta. 1972. 
Feith. Herbert. The Decline of Constitutional Democracy in Indonesia, New York: Cornell University Press, Ithaca, 1962.

Friedmann, W.. Legal Theor 1, London: Stevens \& Sons Limited, 1960.

Gautama. Sudargo. Pengertian Tentang Negara Hukum. Bandung: PT. Alumni, 1983.

Gillin. J.L. and J.P. Gillin. Cultural Sociology, New York. 1948.

Harsojo. Pengantar Antropologi, Cetakan Ke-3, Bandung: Binacipta, 1977.

Hatta. Mohammad. Sekitar Proklamasi, Jakarta: Tintamas, 1970.

Indra, Muhammad Ridhwan. H. Undang-Undang Dasar 1945 Sebagai Karya Manusia, Jakarta: Pustaka Sinar Harapan, 1990.

Ismani HP. Dasar-dasar Ilmu Pemerintahan, Malang: FIA UNIBRAW dan IKIP Malang, 1996.

Iswjara, Fred. Pengantar Ilmu Politik, Cetakan Ke-5 (Cetakan Ke-1 1964), Bandung: Binacipta, 1974.

Jenkin. Thomas P. The Study of Political Theory, New York: Doubleday \& Company, Garden City, 1955.

Jennings. Sir William Ivor. The Law and the Constitution, London: University of London Press, 1956.

Joeniarto. Negara Hukum. Yogyakarta: Jajasan Penerbit Gadjah Mada, 1968.

, Sejarah Ketatanegaraan Republik Indonesia, Jakarta: PT. Bina Aksara, 1982.

, Undang-Undang Dasar 1945 Sebagai Hukum Negara Yang Tertinggi. Jakarta: PT. Bina Aksara, 1982.

Kaho, Josef Riwu. Pemerintahan Pusat dan Daerah Di Indonesia, Bina Aksara, Jakarta, 1982.

. Prospek Otonomi Daerah Di Negara Republik Indonesia, Jakarta: PT. Raja Grafindo Persada, 1982.

Kantaprawira, Rusadi. Sistem Politik Indonesia Suatu Model Pengantar, Cetakan Kelima, Bandung: Sinar Baru, 1988.

Kelsen, Hans. General Theory of Law and State, New York: Russell \& Russell, 1973. 
Kusnardi, Moh. dan Bintan R.Saragih. Susunan Pembagian Kekuasaan Menurut Sistem Undang-Undang Dasar 1945, Cetakan Kedua (Cetakan Pertama 1979), Jakarta: PT. Gramedia, 1980.

Kusumaatmadja, Mochtar. Fungsi dan Perkembangan Hukum Dalam Pembangunan Nasional, Bandung: Binacipta, 1970.

Laski, Harold J. Pengantar Ilmu Politika, Djakarta: Jajasan Pembangunan, 1952.

Linton, Ralph. The Study of Man, New York, 1936.

Lipson, Lislie. The Great Issues of Politics: An Introduction To Political Science, New Jersey: Prentice-Hall-Inc., Englewood Cliffs, 1981.

Locke, John, Two Treatises of Civi! Government, New York: Hafner Publishing Company, 1965.

Logemann. J.H.A. Tentang Teori Suatu Hukum Tata Negara Positif (Over de Theorie van een Stellig Staatsrecht), Penerjemah Makkatutu dan J.C. Pangkerego. Jakarta: Ichtiar Baru-Van Hoeve, 1975.

Maarseveen. Henc van and Ger van der Tang. Written Constitutions. A Computerized Comparative Study, New York Oceana Publications, Inc., Dobbs Ferry, 1978.

MacBrain, H.L. and L. Rogers. The New Constitutions, Doubleday Page, 1922.

MacIver, Robert M. Society. An Introductory Analysis, 1955. , The Modern State. Oxford University Press, London, 1960.

. The Web of Government, New York: The Macmillan Company, 1961 .

Mahfud MD., Moh. Demokrasi dan Konstitusi Di Indonesia Studi Tentang Interaksi Politik dan Kehidupan Ketatanegaran, Jakarta: PT. Rineka Cipta, 1993.

Mahmassani, Subhi Rajab. Konsep Dasar Hak-hak Asasi Manusia Studi Perbandingan Dalam Syariat Islam dan Perundang-undangan Modern (Arkān Huquq'l-Insān, Beirut, 1979), Diterjemahkan oleh Drs.Hasanuddin, Cetakan Pertama. Jakarta: PT. Tintamas Indonesial 993 . 
Mahendra, Yusril Ihza. Dinamika Tata Negara Indonesia Kompilasi Aktual Masalah Konstitusi, Dewan Perwakilan, dan Sistem Kepartaian, Jakarta: Gema Insani Press, 1996.

Manan, Bagir. Dasar-dasar Perundang-undangan Indonesia, Jakarta: Ind-HillCo., 1992.

, Hubungan Antara Pusat dan Daerah Menurut UUD 1945, Jakarta: Pustaka Sinar Harapan, 1994.

Marshall, Geoffrey. Constitutional Theory, At The Clarendon Press: Oxford. 1971.

Mas Soebagio. Lembaran Negara Republik Indonesia Sebagai Tempat Pengundang-an Dalam Kehidupan Ketatanegaraan, Jakarta: PT. Rineka Cipta, 1993.

Merriam, Charles E. Political Power, New York: McGraw Hill, 1934. , Systematic Politics, Chicago: University of Chicago Press, 1957.

, Pertumbuhan dan Perkembangan Konstitusi Suatu Negara, CV. Bandung: Mandar Maju, 1995. , dan Kuntana Magnar, Beberapa Masalah Hukum Tatanegara Indonesia, Bandung: PT. Alumni, 1993.

Montesquieu, Charles de Secondat Baron de Labriede, et de. The Spirit of Laws (L'Ésprit des Lois), Translated from the Frence by Thomas Nugent, LLD., London, 1823.

Moore, Russel F. Modern Constitutions, Littlefield: Adams \& Co., 1957.

Nickel, James W. Hak Asasi Manusia Refleksi Filosofis Atas Deklarasi Universal Hak Asasi Manusia (Making Sense of Human Rights Philosophical Reflection on the Universal Declaration of Human Rights, University of California Press, 1987), Penerjemah Titis Eddy Arini, Cetakan Pertama, Jakarta: PT. Gramedia Pustaka Utama, 1996.

Notohamidjojo, O. Demokrasi Pantjasila (Dasar Nasional Untuk Negara), DJakarta: BPK, 1970.

Notonagoro. Beberapa Hal Mengenai Falsafat Pancasila, Cetakan Kesepuluh (Cetakan Pertama 1967), Jakarta: Pantjuran Tudjuh, 1982.

Poggi, Gianfranco. The Development of the Modern State, A Sociological Introduction, London: Hutchinson, 1978. 
Purbacaraka, Purnadi dan Soerjono Soekanto. Perihal Kaedah Hukum, Bandung: PT. Alumni, 1979.

Rahardjo, Satjipto. Ilmu Hukum, Bandung: PT. Alumni, 1986.

Riyanto. Astim. Teori Konstitusi, Cetakan Kedua (Cetakan Pertama 1993), Bandung: Yapemdo, 2000. - Filsafat Hukum, Cetakan Pertama, Bandung: Yapemdo, 2003.

Sastrawijaya, Safiyudin. Sekitar Pancasila, Proklamasi \& Konstitusi, Bandung: PT. Alumni, 1980.

Sastrosoehardjo, Soehardjo. Konstitusi \& Demokrasi Beberapa Pemikiran Tentang Hukum, Semarang: Dahara Prize, 1991.

Sayre, Wallace S., American Government, New York: Barnes \& Noble Inc., 1966.

Schmid, J.J. von. Ahli-ahli Pikir Besar Tentang Negara dan Hukum (Dari Plato sampai Kant), Diterjemahkan oleh R.Wiratno, Djamaluddin Dt. Singomangkuto, dan Djamadi, Jakarta: PT. Pembangunan, 1988.

Simorangkir. J.C.T. Penetapan UUD Dilihat Dari Segi Ilmu Hukum Tata Negara Indonesia, Jakarta: PT. Gunung Agung, 1984.

, dan B. Mang Reng Say. Tentang dan Sekitar Undang-Undang Dasar 1945, Jakarta: PT. Djambatan dengan Penerbit Bhratara, 1966.

Suny, Ismail. Mekanisme Demokrasi Pancasila, Jakarta: Aksara Baru, 1987.

Soehino. Hukum Tatanegara Negara Kesatuan Republik Indonesia Berdasarkan Pancasila dan Undang-Undang Dasar 1945 Adalah Negara Hukum. Edisi Pertama, Cetakan Pertama, Yogyakarta: Liberty, 1985.

Soekanto, Soerjono. Pokok-pokok Sosiologi Hukum, Jakarta: CV. Rajawali, 1983.

Soewardi. Hak-hak Dasar Konstitusi Demokrasi Modern, PT. Pembangunan, Djakarta, 1957.

Solly Lubis, M. Asas-asas Hukum Tata Negara, Bandung: PT. Alumni. 1978. , Ketatanegaraan Republik Indonesia. Bandung: Mandar Maju, 1993.

Soltau, Roger H., An Introduction to Politics, London: Longmans, Green \& Co., 1961 . 
Sri Soemantri Martosoewignjo, R.H. Demokrasi Pantjasila Dan Implementasinya Menurut/Dalam Undang-Undang Dasar 1945, Bandung: PT. Alumni, 1969.

, Tentang Lembaga-Lembaga Negara Menurut UUD 1946 , Bandung: PT. Alumni, 1986.

, Bunga Rampai Hukum Tata Negara Indonesia, Bandung: PT. Alumni, 1992.

Steenbeek, J.G. De Beproefde Grondwet, Inaugurele Rede, Vuga Boekerijk/ Uitgeverij Vuga NV. 'S-Gravenhage, 1967.

Steinmetz, S.R. Inleiding tot de Sociologie, 1952.

Strong, C.F. Modern Political Constitutions An Introduction to the Comparative Study of their History and Existing Form, Fifth Printed, London: Sidgwick \& Jackson Limited, 1960.

Sunaryati Hartono, C.F.G. Apakah the Rule of Law Itu ?, Bandung: PT. Alumni, 1969.

Suwarno, P.J. Tata Negara Baru Sistem Pemerintahan Yang Demokratis dan Konstitusional, Yogyakarta: Yayasan Kanisius, 1999.

Syafrudin, Ateng. Titik Berat Otonomi Daerah Pada Daerah Tingkat II, CV. Bandung: Mandar Maju, 1990.

Thaib, Dahlan, Pancasila Yuridis Ketatanegaraan, Yogyakarta: AMP YKPN, 1991.

, Implementasi Sistem Ketatanegaraan Menurut UUD 1945, Edisi Kedua, Yogyakarta: Liberty, 1993.

, Jazim Hamidi, dan Nimatul Huda, Toeri Hukum dan Konstitusi, Jakarta: PT. Raja Grafindo Persada, 1999.

Tylor, Edward Burnett. Primitive Culture, London: 1871.

Wahjono, Padmo. Negara Republik Indonesia, Jakarta: Rajawali, 1986.

Wheare, Kenneth C. Modern Constitutions, London, New York: Toronto, Oxford University Press, 1975.

Yunas, Didi Nazmi. Konsepsi Negara Hukum, Padang: Angkasa Raya, 1992.

Yamin, Muhammad, H. Proklamasi dan Konstitusi Republik Indonesia, Jakarta: PT. Djambatan, 1954. 
, Naskah-Persiapan Undang-Undang Dasar 1945, Jilid Pertama, Jakarta: Yayasan Prapantja, 1959.

. Naskah-Persiapan Undang-Undang Dasar 1945, Jilid Kedua, Jakarta: Yayasan Prapantja, 1960.

, Naskah-Persiapan Undang-Undang Dasar 1945, Jilid Ketiga, Jakarta: Yayasan Prapantja, 1960. [t.t.].

, Pembahasan Undang-Undang Dasar Republik Indonesia, [t.p.],

\section{Peraturan Perundang-Undangan}

Indonesia, Undang-Undang Dasar Negara Republik Indonesia Tahun 1945, Lembaran Negara 1959 Nomor 75.

, Perubahan Pertama Undang-Undang Dasar Negara Republik Indonesia Tahun 1945, Ditetapkan oleh MPR RI tanggal 19 Oktober 1999.

, Perubahan Kedua Undang-Undang Dasar Negara Republik Indonesia Tahun 1945, Ditetapkan oleh MPR RI tanggal 18 Agustus 2000.

, Perubahan Ketiga Undang-Undang Dasar Negara Republik Indonesia Tahun 1945, Ditetapkan oleh MPR RI tanggal 9 November 2001.

, Perubahan Keempat Undang-Undang Dasar Negara Republik Indonesia Tahun 1945. Ditetapkan oleh MPR RI tanggal 10 Agustus 2002 .

, Undang-Undang RI Nomor 5 Tahun 1998 tanggal 28 September 1998 tentang Pengesahan Convention Against Torture and Other Cruel, Inhuman or Degrading Treatment or Punishment (Konvensi Menentang Penyiksaan dan Perlakukan atau Peng-hukuman Lain Yang Kejam, Tidak Manusiawi, atau Merendahkan Martabat Manusia.

, Undang-Undang RI Nomor 39 Tahun 1999 tanggal 23 September 1999 tentang Hak Asasi Manusia.

. Undang-Undang RI Nomor 26 Tahun 2000 tanggal 23 November 2000 tentang Pengadilan Hak Asasi Manusia.

Ketetapan MPR RI No. XVII/MPR/1998 ttanggal 13 November 1998 tentang Hak Asasi Manusia. 
Keputusan Presiden RI Nomor 50 Tahun 1993 tanggal 7 Juni 1993 tentang Komite Nasional Hak Asasi Manusia.

. Nomor 129 Tahun 1998 tanggal 15 Agustus 1998 tentang Rencana Aksi Nasional Hak-hak Asasi Manusia Indonesia.

. Nomor 181 Tahun 1998 tanggal 9 Oktober 1998 tentang Komisi Nasional Anti Kekerasan Terhadap Perempuan.

Instruksi Presiden RI Nomor 26 Tahun 1998 tanggal 16 September 1998 tentang Menghentikan Penggunaan Istilah Primbumi dan Nonpribumi Dalam Semua Perumusan dan Penyelenggaraan Kebijakan. Perencanaan Program, Ataupun Pelaksanaan Kegiatan Penyelenggaraan Pemerintahan.

\section{Deklarasi dan Perjanjian/Persetujuan Nternasional}

Perserikatan Bangsa Bangsa (PBB), Deklarasi Universal tentang Hak-hak Manusia (Universal Declaration of Human Rights), disahkan oleh Majelis Umum PBB tanggal 10 Desember 1948.

, Deklarasi Vienna dan Program Aksi (The Vienna Declaration and Programme of Action), Hasil Konferensi Dunia Hak Asasi Manusia bulan Juni 1993.

, Perjanjian Internasional Khusus Tentang Hak-hak Sipil dan Politik (International Covenant on Civil and Political Rights). diratifikasi oleh Majelis Umum PBB tanggal 16 Desember 1966.

, Perjanjian Internasional Khusus Tentang Ekonomi, Sosial dan Kebudayaan (International Covenant on Economic. Social and Cultural Rights), diratifikasi oleh Majelis Umum PBB tanggal 16 Desember 1966.

Persetujuan Melawan Diskriminasi Dalam Pendidikan (Convention Against Discrimination in Education), dikeluarkan oleh UNESCO tahun 1960.

, Persetujuan Internasional Untuk Menghilangkan Bentuk-bentuk Diskriminasi Rasial (International Convention on Elimination of all forms Racial Discrimination), dikeluarkan oleh PBB tahun 1965. 